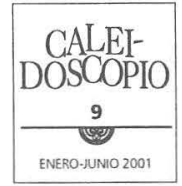

\title{
"Para tu favor y ayuda" El Confesionario mayor de fray Alonso de Molina, como texto para enseñar a vivir su nueva religión a los indios mexicanos recién convertidos al cristianismo.
}

BENJAMINN FLORES HERNĀNDEZ

Departamento de Historia/UAA

Y por tanto conviene que sepas, que la raíz y fundamento de tu salvación es el conocimiento de tus pecados, y este conocimiento de tus pecados con el cual conoces y confiesas tus iniquidades y lo poco que eres, es principio y fundamento del conocimiento de la sabiduría divina, conocimiento que nace también y tiene principio del temor de Nuestro Señor; y destas dos cosas, conviene a saber del conocimiento del pecado y del temor de Dios, tiene principio y procede la contrición y arrepentimiento de los pecados.

Fray Alonso de Molina, Confesionario mayor en la lengua mexicana y castellana.

P arte fundamental dentro de la práctica religiosa católica resultaba ya, al finalizar el segundo tercio del siglo XVI, el sacramento de la penitencia y, en éste, la confesión auricular. ${ }^{1}$ Sucede que la noción del pecado como una ofensa a Dios, como infracción de sus leyes reveladas a Moisés en el Sinaí y de los preceptos dictados después por la Iglesia fundada por su Hijo Jesucristo y, asimismo, consecuencia de ella, la idea de una fórmula litúrgica para implorar de la divinidad el perdón de esa falta, ya represen-

1 No es el caso de recorrer aquí la historia de la manera en que la absolución del infractor tras la confesión auricular con un sacerdote llegó a consolidar- 
taban para entonces unos de los conceptos más importantes de la doctrina del catolicismo. Dentro de la historia sagrada reconocida por éste, el lugar que ocupa la responsabilidad del hombre por sus acciones frente al Creador es tan primordial que de ella se deriva el concepto del pecado original que -felix culpa-motivara el acontecimiento histórico central de todos los siglos: la obra de la redención llevada a cabo, mediante su encarnación, muerte y resurrección, por la segunda persona de la Trinidad.

se en la Iglesia católica. Lo mismo que los demás sacramentos, el de la penitencia fue muy controvertido a través del tiempo, y durante el siglo XVI, precisamente cuando España y los españoles llevaban a cabo la empresa de la conquista militar y espiritual del continente americano, el protestantismo dirigía sus embates en su contra, bien es verdad que todavía no con la furia con que, para el siglo XVII, lo haría el calvinista francés Jean Daillé (1594-1670), quien atribuyera su invención al papa Inocencio III en el IV Concilio de Letrán, al imponer la obligación de la confesión anual. La Iglesia remonta el origen de éste, como de los otros sacramentos, al mismo Jesucristo, y pretende que su práctica se cumplió desde los primeros siglos de su existencia. El Concilio de Trento, que tras 18 años de trabajos dos veces interrumpidos, concluyó el 4 de diciembre de 1563, unos cuantos meses antes de la aparición del Confesionario mayor de fray Alonso de Molina, definió muy bien lo que había que entender por penitencia y por confesión. Lo hizo en su sesión número 14, del 25 de noviembre de 1551, en cuyo capítulo $5^{\circ}$ se dice: "Por la institución del sacramento de la penitencia ya explicada, toda la Iglesia ha entendido siempre que el Señor instituyó la confesión íntegra de los pecados, y que ésta es necesaria a todos los que han caído en ellos después del bautismo. Porque Nuestro Señor Jesucristo, teniendo que subir a los cielos, dejó a los sacerdotes como vicarios suyos, como presidentes y jueces a quienes se delatasen todos los pecados mortales en que cayesen los fieles de Cristo, a fin de que con la potestad de las llaves, de perdonar y retener, pronunciasen la sentencia. Pues consta que los sacerdotes no podían ejercer este juicio sin conocer la causa, ni podían ser equitativos en imponer la pena, si los mismos penitentes sólo se declarasen en general sus pecados y no en particular cada uno de ellos". Enciclopedia universal ilustrada europeo-americana, Madrid, Espasa Calpe, $70+$ 10 tt., artículo "Confesión”, t.14, p. 159. Esta doctrina definida en Trento era la que indudablemente estaba detrás de la composición y edición de libros como este Confesionario... 
Puesto que para lograr la remisión de los pecados resultaba requisito indispensable la agregación a la Iglesia mediante la recepción de las aguas bautismales, la acción de los primeros frailes en territorios que ahora son mexicanos tendió, antes que nada, a procurar la espontánea recepción del bautismo por parte de los naturales. En realidad, a pesar de que para algunos misioneros tal actitud no era muy aceptable, sucedió que el bautizo de los primeros enormes contingentes de indígenas ocurrió cuando éstos no habían oído sino las más elementales nociones de la doctrina cristiana. Pero es que, también, en concepto de muchos, debía considerarse que, ante la urgencia de incorporar a tantos hombres a la Iglesia, ante la necesidad de abrirles la posibilidad de salvarse, de librarlos de una segura condenación, más importaba hacerlos ya cristianos -digamos- de "derecho", por más que, por sus auténticos conocimientos de las verdades de la religión, no lo fueran todavía efectivamente de "hecho".

Y, para la remisión de las faltas cometidas después de bautizados, estaba el sacramento de la penitencia, con el humilde reconocimiento de ellas ante un sacerdote representante de Jesús. Precisamente para preparar a los indígenas para la participación en este misterio litúrgico fue que fray Alonso de Molina redactó el Confesionario de que aquí se tratará. ${ }^{2}$ Ayudar a los aborígenes

2 Fray Alonso de Molina compuso dos confesionarios: el "mayor" que aquí se revisa - Confesionario mayor en la lengua mexicana y castellana-, para los indígenas, y el "breve", más bien destinado a los confesores. Ambos confesionarios se presentan en dos columnas, una en castellano y la otra en náhuatl. De cada uno se hicieron tres ediciones, todas en México, durante el siglo XVI: las dos primeras de ambos las realizó Antonio de Espinosa en 1565 y 1569, respectivamente, y la tercera Pedro Balli, la del "breve" en 1577 y la del "mayor" en 1578. Para una descripción bibliográfica y tipográfica de esas seis ediciones véase Joaquín García Icazbalceta, Bibliografía mexicana del siglo XVI. Catálogo razonado de libros impresos en México de 1539 a 1600. Con biografías de autores y otras ilustraciones, precedido de una noticia acerca de la introducción de la imprenta en México, ed. de Agustín Mi- 
para su confesión implicaba, indispensablemente, el dato seguro de su cristianismo previo.

En general, la labor de enseñar a los americanos los artículos de fe del cristianismo y los deberes a los que esa religión los obligaba, fue posterior al acto de la simple adopción formal de la nueva creencia. Así, cuando aquí se habla de evangelización a lo que se hace referencia sobre todo es a esa etapa de adoctrinamiento de indígenas ya bautizados a los que, poco a poco, sin las prisas de la primera hora, se les estaban comunicando las nociones esenciales sobre lo que, en la práctica, quería decir ese su ya aceptado cristianismo.

Son muchos y muy interesantes los métodos e instrumentos adoptados por los evangelizadores del siglo Xvı para enseñar la fe a los indios neófitos. Debe hacerse hincapié en el hecho de que tal tarea la llevaron a cabo, fundamentalmente, en las lenguas e idiomas propios del país, y muy particularmente en náhuatl, que en mucho funcionó como una lingua franca para esta empresa. Son infinidad los catecismos y doctrinas que, por este tiempo, se redactaron en varios idiomas nativos; el propio fray Alonso de Molina, autor del Confesionario a cuyo estudio se dedica este trabajo, compuso además dos Doctrinas, una corta y otra más larga, en la misma lengua mexicana. ${ }^{3}$ Las técnicas catequísticas enton-

llares Carlo, $2^{a}$., ed., revisada y anotada, México, Fondo de Cultura Económica, 1981, 591 pp., láms., (Biblioteca Americana), pp. 190-192, 220-221, 283 y 285-286.

3 En su obra La conquista espiritual de México. Ensayo sobre el apostolado y los métodos misioneros de las órdenes mendicantes en la Nueva España de 1523-24 a 1572, tr. de Ángel María Caribay K., México, Editorial Jus. Editorial Polis, 1947, 557 pp., (Colección de estudios históricos), pp. 214217) Robert Ricard coloca precisamente a la Doctrina de Alonso de Molina, impresa bajo el patrocinio del obispo fray Juan de Zumárraga entre 1544 y 1546, como el ejemplo típico de los textos utilizados.por los frailes, y aun el clero secular, para la enseñanza del cristianismo a los indígenas. Por cierto que de este libro, que debió alcanzar una amplísima difusión y cuya exis- 
ces utilizadas conocieron una enorme riqueza imaginativa, y algunas de ellas poseyeron un notabilísimo interés pedagógico. En fin: que la faena llevada a cabo por los frailes evangelizadores, naturalmente sujeta a todas las fallas humanas, contó desde luego, cuando menos, con el notable entusiasmo de los mejores de los hombres que intervinieron en ella.

Un instrumento que resultó muy interesante para completar la empresa del adoctrinamiento de los ya convertidos fue éste de los confesionarios. Originalmente, la función de estos libritos es la de meros auxiliares del feligrés en su preparación para el sacramento de la penitencia, la de ayudarlo a desarrollar su examen de conciencia previo al acto de acercarse al sacerdote a manifestarle sus pecados y solicitarle la absolución de ellos. Así pues, en principio, no consisten sino en un breve repaso de los ordenamientos de la religión para auxilio del creyente en su recuento de ellos, a ver cuáles ha contravenido. Pero para los americanos recién incorporados a la religión católica, ese tipo de escritos, al poner ante su consideración la lista de los mandamientos de Dios y de la Iglesia, desempeñó una función, muchas veces, más de enseñanza que de simple recordatorio. No podían dudar los frailes autores de los tales opúsculos de que los indios fueran ya, por el solo hecho de su bautizo, cristianos cabales, pero también les constaba que su conocimiento de las verdades de la religión todavía dejaba mucho que desear.

Indudablemente que tales confesionarios estaban muy inspirados en los muchos que circulaban en Europa, simple traducción o adecuación de los cuales, en buena parte, podría parecer éste. Mas lo característico del nuestro es el destino preciso que iba a tener: ayudar, concretamente, a los indígenas mexicanos a prepararse para su confesión, trayéndoles a las mientes las varia-

tencia probó fehacientemente Joaquín García Icazbalceta, no se conservan ejemplares. 
das formas en que podían haber ofendido a Dios. Y no son sólo las interesantísimas alusiones que allí aparecen sobre la vida de los aborígenes mesoamericanos del tercer cuarto del siglo XVI, muy particularmente referentes a supervivencias de la época prehispánica, lo que habrá de cautivarnos en él. Es todo el enfoque de su texto a doble columna, una en castellano y otra en náhuatl para enfatizar que intentaba llegar hasta lo más íntimo del alma de los naturales, lo que lo hace una obra fundamental para el conocimiento de la circunstancia histórica en la que fue escrito.

Los indios mexicanos de lengua náhuatl a quienes iba dirigido este texto eran ya cristianos bautizados, debía suponerse que sinceros convencidos de la verdad de la fe a la que habían decidido adherirse. De lo que se trataba, ahora, era de que la asumieran hasta sus últimas consecuencias, de que fueran, con todos los defectos y debilidades humanas, buenos, auténticos cristianos. A este empeño iba dirigido el Confesionario mayor. Su intención era la de hacer repasar al indígena las obligaciones de conducta a que lo instaba su catolicismo. A hacer algunas consideraciones acerca del sentido general de las tales recordaciones es a lo que tratará de ceñirse el presente artículo. Obviamente, todas las indicaciones, los consejos, las apreciaciones de fray Alonso de Molina tienen como punto de partida la doctrina católica más ortodoxa: en todo momento quiere dejar patente el franciscano su absoluta sujeción a los principios sostenidos por la Iglesia. Pero, claro, también es cierto que su propio catolicismo no puede menos que estar marcado, en buena medida, por su existencia y actividad dentro de un momento y de un ambiente determinados. Lo que pretenderán las páginas siguientes será ver cuál es la imagen que de la religión católica aparece en el Confesionario mayor, es decir, según era enseñada a los indígenas. Debe entenderse que, antes que nada, lo que dicha obra quiso ser fue un repaso, lo más completo posible, de cómo debía ser una religión cristiana bien vivida, de cuáles eran las faltas que los naturales que habla- 
ban náhuatl y que ya se habían convertido podían cometer en contra de los mandamientos de Dios y de la Iglesia para que se arrepintieran de ellas, las confesaran ante el sacerdote y, luego, se esforzaran para no volver a incurrir en ellas.

Vale la pena enfatizar en esa doble dimensión del Confesionario: está por una parte indudablemente dirigido a la predicación de unos personajes muy concretos, los indios mexicanos del último tercio del siglo XVI, y a atender a ciertas circunstancias muy particulares suyas dedica su principal interés, pero al mismo tiempo no deja de tener una inspiración generalizadora, en tanto que todos los preceptos del cristianismo obligan por igual a todos los hombres y mujeres de cualquier lugar y tiempo.

\section{Generalidades}

Realmente fue providencial para la evangelización que, en fecha desconocida que debió ser muy cercana a la consumación de la conquista militar, se hubiera ya instalado en México una señora española viuda, cuyos dos pequeños hijos, seguramente jugando, muy pronto habían aprendido a la perfección el náhuatl, sabido lo cual por los recién llegados frailes franciscanos, pidieron a Hernán Cortés les consiguiera que uno de ellos pasara a ser su ayudante a modo de que, guardándolo consigo en el convento, se convirtiera en el intérprete que les urgía para darse a entender con sus catecúmenos durante los primeros tiempos. Ni el capitán conquistador ni la honrada madre del rapaz tuvieron inconveniente en acceder a esa petición, y lo cierto es que tanto se llegó a identificar el niño con sus tutores que, con el tiempo, profesó dentro de la orden, recibió la consagración sacerdotal y desempeñó algunos cargos en varias casas franciscanas.

Se ha conjeturado que este religioso, fray Alonso de Molina, debió haber nacido en Extremadura, alrededor de 1514. Se supone, asimismo, que su fallecimiento ocurrió por 1585 -Zulaica- o 1579 -León Portilla-. De cierto sólo se sabe que en 1555 fungió 
como guardián en Texcoco, en 1569 en el convento de Tecamachalco, en 1572 en el de Tlatelolco y, en alguna otra ocasión, también en el de Puebla. No son muchos más los datos que se poseen acerca de la vida de este fraile, del cual, en cambio, se conoce que llegó a funcionar como uno de los más notables nahuatlatos de aquel siglo. Su producción en el idioma mexicano es muy abundante, y abarca los dos confesionarios ya mencionados, dos doctrinas cristianas, un Arte de la lengua mexicana y, la más conocida de todas sus obras en la actualidad, el Vocabulario en lengua castellana y mexicana y en lengua mexicana y castellana; también fueron suyos otros escritos que sólo se conocen por referencia, tales una vida de San Francisco de Asís y un buen número de traducciones al náhuatl de textos del Nuevo Testamento, oraciones y sermones.

De cualquier modo, debe tenerse muy en cuenta que una obra como la que aquí se va a estudiar no es propiamente personal. Naturalmente que es compuesta por alguien muy concreto, con una individualidad muy específica, pero trata de ser, ante todo, la expresión de una doctrina que, se sabe muy bien -y ésa es, por lo demás, la más estricta garantía de su validez- rebasa todo sentido personalista y se aboca a una trascendencia de pretensiones universales: en el Confesionario mayor del padre Molina -como en cualquier otro trabajo de esa misma clase- lo que trata de expresarse no son de ningún modo puntos de vista propios, sino la doctrina de la Iglesia; como dijera el propio fray Alonso, respecto de sus obras: "Y todo lo que en ellas tractare, someto a la corrección de la sancta madre Yglesia, no pretendiendo en ellas otra cosa alguna, sino lo que ella tiene y confiesa". ${ }^{4}$

4. Alonso de Molina, Confesionario mayor en la lengua mexicana y caslellana (1569), intr. por Roberto Moreno, [México], Boletín del Instituto de Investigaciones Bibliográficas 7, enero-junio de 1972, 34 pp., 124 ff., (Suplemento al Boletín del Instituto de Investigaciones Bibliográficas, 1), Carta nuncupatoria, f. 2 v. 
Claro que tal apego a los principios universales del catolicismo se da en nuestro autor según eran éstos entendidos, concretamente, en la época en la que escribe, por los franciscanos y por los españoles.

El interés del libro que habrá de comentarse es enorme. Incluso si no se tratara más que de la traducción de un catecismo europeo no dejaría de ser muy útil su revisión puesto que, como comenta la maestra Elsa Frost, "este tipo de libros es testimonio de una empresa claramente definida: la cristianización del indio". 5

Fray Alonso de Molina fechó la terminación de su Confesionario mayor en la lengua mexicana y castellana, en la epístola nuncupatoria -es decir, aquella en la que dedica la obra-dirigida al arzobispo de México fray Alonso de Montúfar, en el convento de San Francisco de México el 6 de noviembre de 1564. La obra conoció, pronto, tres impresiones, en 1565, 1569 y 1578, lo que habla de la magnitud de su difusión. La edición que sirvió de base para la elaboración de este trabajo es una moderna de 1972, la cual reproduce facsimilarmente la segunda, de 1569; apareció como suplemento al número 7 del Boletín del Instituto de Investigaciones Bibliográficas de la Universidad Nacional Autónoma de México, con prólogo del maestro Roberto Moreno y de los Arcos.

Con todo y su sentido universalista y de pretender considerar a los indígenas mexicanos -a quienes específicamente estaba dedicado- como cristianos cabales, sin ninguna diferencia con los europeos, la verdad es que a lo largo del Confesionario son muchas las notas que aparecen alusivas a características y cir-

5 Elsa Cecilia Frost, "Sobre Alonso de Molina: Confesionario mayor en lengua mexicana y castellana (1569)", en Historia mexicana, México, El Colegio de México, v. XXVII, no. 2, octubre-diciembre 1977 (106), pp. 316320, pp. 316-317. Es de justicia mencionar aquí que la primitiva redacción de este artículo data de cuando cursé el seminario de Historiografía colonial mexicana, que hace ya muchos años impartía la maestra Frost en la División de Estudios de Posgrado de la Facultad de Filosofía y Letras de la Universidad Nacional Autónoma de México. 
cunstancias muy propias del mundo mestizo mexicano del tercer cuarto del siglo XVI. Muy particularmente, tales referencias a lo nativo aparecen al hablar el autor de los posibles pecados cometidos contra los mandamientos primero y séptimo de la ley de Dios. Tocante al primero, se trata de supervivencias del paganismo que debían ser bastante frecuentes; referente al séptimo, hay allí una amplísima descripción de la realidad del país. Por ejemplo, cuando señala qué es lo que pudo robar un indígena, no se le ocurre a fray Alonso sino elaborar una enorme lista de ciertos bienes de valor en la época y en la zona, la cual va así:

\footnotetext{
Hurtaste alguna cosa, assí como mantas: tomines, gallinas, oveja o buey: o por ventura algún cavallo, oro: o plata, plumas; o plumajes ricos; algunas joyas, $o$ axorcas: o cogiste el mayz de la heredad de otro: o sembraste tierras agenas: o quizá tomaste algunas mazorcas de mayz, calabazas, axí, frisoles: chía: o cortaste madera o leña en monte ageno? ${ }^{6}$
}

También se hacen, incidentalmente, alusiones a algunas formas de la vida propia del México mestizo de entonces. Por citar un solo ejemplo de esto, allí están, al tratarse del quinto mandamiento de Dios, las preguntas específicas que se hacen a los médicos indígenas, que todavía usaban yerbas y medicinas de las utilizadas desde el tiempo de su gentilidad. A ellos inquiría fray Alonso, respecto al buen o mal desempeño que hubieran tenido en su profesión: "Has bien estudiado la medicina y arte de curar: o haste fingido médico, y no conoces las yervas y rayzes medicinales que das, para curar las enfermedades: y a esta causa, enfermó y murió el enfermo?"7

Por lo demás, el hecho de que su texto se presente en dos columnas, con las versiones castellana y náhuatl, que de este modo pueden compararse párrafo a párrafo, incrementa su interés para

6 Molina. op. cit.., $7^{\circ}$ mandamiento de Dios, f. 35v.

7 Ib., $5^{\circ}$ mandamiento de Dios, f. 31v. 
el estudioso contemporáneo del mundo novohispano del siglo XVI, particularmente en lo cultural, lo lingüístico y lo religioso.

UNA REGLA DE VIDA

Fundamentalmente, como su nombre lo indica, la función que debía tener el Confesionario era la de preparar a los cristianos neófitos para una buena confesión. De lo que se trataba era de presentar a los recién convertidos las posibles maneras en que habían ofendido a Dios, en que se habían apartado de la buena vida que les exigía su nueva religión, para hacer el examen de conciencia previo a su acercamiento al sacerdote a fin de solicitarle la absolución de sus pecados.

La religión cristiana exige una forma de vida, de acuerdo a la voluntad de Dios, infringir la cual resulta pecado. Así pues, al ayudar al católico a examinarse, al presentársele las posibles ofensas que había hecho a su Creador, se está definiendo, simultáneamente, en contraste, cuál sería la vida adecuada que debía llevar. En este sentido, lo que expresa Alonso de Molina es, precisamente, una regla de vida.

Y se trata de que quien va a confesarse haga un examen de conciencia acerca de lo que ha sido su existencia desde la última vez que haya recibido ese sacramento. Hace falta que ese examen sea lo más exhaustivo posible pues de no ser así, si al manifestarse los pecados al sacerdote falta alguno, la confesión será no sólo inválida, sino sacrílega:

Y si primero no truxeres a la memoria tus pecados, y los ayuntares y recogeres será tu confessión inválida, falsa y no verdadera, ni menos será útil y provechosa a tu ánima, antes la afligirás mucho más, y no será para tu favor y ayuda la tal confessión. Más para tu confussión, y condenación, y para que eternamente seas desechado. ${ }^{8}$

$8 \quad$ Ib., Amonestación, f. 9v. 
Por lo demás, hace falta que el hombre se conozca a sí mismo, revisando en su interior lo que ha sido su vida; como dice el fraile, "la derecha sabiduría, que se llama Philosophía, es el conocimiento de sí mismo".?

Conociéndose uno, las propias faltas, se consigue luego el mejor conocimiento de Dios: "Y si no merecieres ni fueres digno de conoscerte primero, y de entender qué tal seas, y si ante todas cosas no te considerares, tampoco merecerás ver ni contemplar al único y solo Dios, ni podrás tener conoscimiento de su magestad con la vista de tu ánima". ${ }^{10}$

Sólo sabiendo quién es de verdad el hombre, sus limitaciones y grandezas, es que puede entenderse de verdad la magnitud enorme de su Autor.

En primer lugar, la vida del cristiano ejemplar, según el modelo propuesto por Molina, ha de estar dirigida a Dios, en quien se encuentra la única razón, el único sentido de la existencia. Todo el pensamiento y la acción han de estar referidos al Padre, en cada momento de la vida:

Dexaste por ventura, de te ocupar y ofrecer tu entendimiento: a nuestro señor Dios, no te acordando de esse mesmo Dios, ni de las cosas que a Él pertenecen, dejando de aprender las cosas divinas, que en este mundo nos ha comunicado el único Dios y señor nuestro, mediante el qual todas las cosas biven, y las cosas del cielo que emos de alcanzar, después de esta vida, teniendo por ventura solamente cuydado de las cosas terrenales[...]? ${ }^{11}$

Quien deja de considerar a Dios como principal motor de su existencia, quien intenta hacer de otra persona o cosa el centro de su vida peca grandemente, trastoca la jerarquía de los valores, no se comporta como verdadero cristiano: "Porque has de saber, que el que se aficiona y ama mucho las cosas terrenales, luego se haze

$9 \quad I b .$, Prólogo, f. 6.

$10 \quad I b .$, f. $5 v$.

$11 \quad I b .$, Potencia del entendimiento, ff. 103v y 104. 
enemigo de nuestro señor Dios. Mas el verdadero christiano, no se deleyta en las cosas mundanas, que engañan, mas deléytase en las cosas del cielo, que después se han de alcanzar". ${ }^{12}$

De Dios sólo ha recibido el hombre beneficios; todo lo bueno de la vida a Él se le debe. ¿Qué menos que conservar siempre, en agradecimiento, en la memoria, los muchos favores que continuamente dispensa?

Dexaste por ventura de considerar, y pensar los muchos beneficios y mercedes y gracias, que te ha hecho y comunicado nuestro señor Dios (especialmente, el averte criado antes que tuviesses algún ser) y averte redimido y librado (después que por tus pecados avías perecido) padeciendo por ti muchos trabajos y angustias, y sufriendo grandes aflicciones y penalidades, y padeciendo por tu amor muerte de cruz,y ofreciéndose: y dándosete assi mesmo, en el Sanctíssimo Sacramento, y adoptándote en hijo suyo: y teniendo siempre cuydado de ti, assí en lo que concierne a tu ánima, como a tu cuerpo, y ofreciéndote liberalmente el reyno de los cielos (si le amaras y guardares su ley y mandamientos) $?^{13}$

Lo que propone fray Alonso de Molina en esta obra suya es el culto fervoroso a Dios, y la vida según sus mandamientos transmitidos a través de su Iglesia. La vida "santa y buena" es, precisamente, la querida por Dios, según lo enseña la Iglesia. Así, apunta fray Alonso que, al confesarse, el penitente debe abrigar el propósito firme de "aver de comenzar de nuevo y con gran perseverancia la vida sancta y buena no dexarás de reesforzar quanto pudieres, y de te animar mucho a obedecer promptíssimamente a tu Dios y señor, y a tu madre la sancta iglesia". ${ }^{14}$

La forma de adhesión a Dios ha de ser, precisamente, la de vivir fielmente dentro de la Iglesia. En un tiempo de herejías en Europa y de peligros de volver a lo pagano en América, la única

\footnotetext{
12 Ib., Caridad, f. 110.

13 Ib., Memoria, ff. $104 \mathrm{v}$ y 105.

14 Ib., Amonestación, f. 16.
} 
garantía de ortodoxia es la plena adicción a la Iglesia; la menor duda con respecto a las enseñanzas de ésta podía ser indicio de pecado. Y así lo manifiesta el padre Molina al interrogar al catecúmeno con respecto a su fe:

Tuviste por ventura alguna vez duda acerca de los artículos de la sancta fee cathólica: o dexaste de creerla, de la manera que la cree nuestra madre sancta yglesia: 0 pensaste alguna vez y creyste, que no venían de la mano de Dios, todas aquellas cosas: que te declara y manifiesta, la sancta madre yglesia? Porque te es necessario el tener entendido y creydo que no son inventadas de los hombres deste mundo, mas que el mismo Señor nuestro, encomendó, reveló, manifestó y mostró a la dicha yglesia, todas las cosas que se deben creer, y las palabras suyas, concernientes a nuestra salvación: y las que por su mandado, fueron comunicadas y declaradas a los prophetas y apóstoles, que son todas aquellas que cree y tiene la sancta madre yglesia. ${ }^{15}$

Y la adhesión a tales doctrinas de la Iglesia debía ser hasta las últimas consecuencias, hasta la muerte, incluso, si hacía falta. Fray Alonso de Molina lo decía con toda claridad: "Porque eres obligado, de en toda parte, y en todo tiempo, confessar a nuestro Señor, todas las cosas tocantes a su fee, aunque por la dicha fee te quiten la vida $[\ldots]^{\prime 16}$

El ideal de fray Alonso, representante en eso de los misioneros evangelizadores franciscanos, es que cada uno de los convertidos viva devotamente, siempre, en todo momento. Quisiera que los nuevos cristianos fueran mejores que los europeos, que no nada más no pecaran nunca, sino que todas las acciones de su vida fueran las correspondientes a las de quien ha tomado a Jesucristo por su modelo a imitar. Resulta muy completo el catálogo de los preceptos a ser tomados en cuenta por quien ha de ponerse a examinar su conciencia:

$15 \quad I b . .$, Fe, ff. 105 y 105 v.

$16 \quad I b .$, f. 106. 
Assimismo te acordarás, y te examinarás, acerca de la guarda de todos los mandamientos de nuestro señor Dios, y de los mandamientos de la sancta yglesia; acordándote, si quizá también menospreciaste alguno de los sacramentos, que tiene la sancta madre yglesia, los quales eres obligado a rescebir, para te poder salvar: o si por ventura cayste en algún pecado mortal, y si dexaste de creer firmemente todos los artículos de la fee, los quales te manda creer con todo rigor nuestra madre sancta yglesia; quizá alguna vez dudaste en alguno dellos; o si por ventura muchas vezes menospreciaste, y no recebiste alegremente los dones del Espíritu Sancto, y dexaste de hazer todas aquellas cosas sanctas que Él te inspirava e traya a la memoria: y si exercitaste las catorze obras de misericordia, assí las que pertenecen al alma como las que pertenecen al cuerpo: o si dexaste de guardar tus cinco sentidos, que están en tu cuerpo: y si dexaste de te exercitar en todas las virtudes y obras justas y sanctas: las quales se llaman theologales, que son la fee y creencia, la esperanza en Dios, y la charidad encendida, y las quatro cardinales, como es la fortaleza, la templanza, la rectitud y justicia, y la prudencia. $^{17}$

Vivir devotamente, pues. No sólo no pecar, sino dirigir todas las acciones a la gloria de Dios. Vencer la pereza, que a veces impide acudir oportunamente a misa y a oír los sermones, y ocuparse con "affección en la oración, en la yglesia". ${ }^{18}$ Y no perder el tiempo en actividades y diversiones vanas. Para fray Alonso, resulta motivo de reflexión recordar a quien va a confesarse si es que "fuiste muchas vezes a ver juegos, o bayles, o representaciones vanas y de reyr, o a ver correr toros, juegos de cañas, justas y torneos adonde muchas vezes mueren algunos, olvidándote allí de tu Dios y señor, y comətiendo culpas y pecados?"19

17 Ib., Amonestación, f. 16.

18 Ib., Pereza, f. 95.

19 Ib., Sentido de la vista, f. 101v. No puedo dejar de apuntar aquí la extrañeza que me produce a mí, que tanto me he dedicado al estudio de la afición taurina mexicana, el ver aquí considerada como pecado, o cuando menos distracción que convenía evitar, la asistencia a la que, ya para esas épocas en que escribe Molina, era la fiesta nacional de la hispanidad. 
El devoto cristianismo de los indios, tal y como lo querían Molina y los demás frailes misioneros, debía expresarse en todas y cada una de las circunstancias. Por ejemplo, a la hora de redactar su testamento, en cuyo encabezamiento nunca debería faltar toda una declaración de su fe de creyentes y del deseo de aplicar una parte de los bienes que se dejaban al morir a sufragar un cierto número de misas a rezar por su alma. Así, al iniciarse el documento indicador de la última voluntad, aconsejaba el padre Molina colocar las siguientes disposiciones propias de un buen católico:

\begin{abstract}
Primeramente, encomiendo y pongo mi ánima, en las manos de nuestro señor Dios que la crió, y pídole por merced, y supplícole, aya misericordia de mí, y que me quiera perdonar mis pecados, y me quiera llevar a su casa del cielo (después que mi ánima se aya apartado del cuerpo) y el dicho mi cuerpo dexo y encomiendo a la tierra, do salió, porque es tierra y lodo, y quiero que sea embuelto en sola una sávana, para enterrarle y quiero que sea enterrado, en nuestra yglesia de sant Antonio de Padua [por ejemplo]: adonde el sacerdote me señalare sepultura, y enterramiento. Y es mi voluntad, que para ayuda de mi ánima, porque no sea mucho tiempo detenida en purgatorio: se me diga una vigilia y una missa al tiempo que sepultaren mi cuerpo, y si no pudiere ser aquel día: sea el siguiente y llevarán la ofrenda a la yglesia y si quisieren que se celebren por él algunas missas declarará: los pesos que quisiere se den a la yglesia para que dellos se compren ornamenteos o para que se les dé lo necessario al sustentamiento de todos los ministros, etc. ${ }^{20}$
\end{abstract}

La vida propuesta en el Confesionario mayor no sólo debía ser piadosa y referida por entero a lo religioso, sino también ejemplar en cuanto a otros valores, tales la modestia, la humildad, la cortesía e, inclusive, la limpieza y la compostura. Así, se aconseja allí una actitud respetuosa para con los superiores religiosos y civiles, acerca de la cual se comenta, en las preguntas sobre el cuarto mandamiento de la ley de Dios: "Por ventura dexaste de tener

Ib., Cabeza de testamento, f. 6lv. 
reverencia, y de obedecer a los que rigen y goviernan, y tienen cargo de administrar la justicia, quando mandaron alguna cosa justa, antes los dexaste de respectar, y los menospreciaste, o murmuraste dellos, y los disfamaste?"21

La mera limpieza física y la decencia y buen arreglo en el vestido son también considerados como valores aconsejables, claro que principalmente si se les trae a colación, por ejemplo, como disposiciones previas a la recepción de los sacramentos. Así, entre los "aparejos" anteriores a la comunión, el tercero consiste en que "te laves bien, assí la cara como las manos y la boca, y te peynes, y que tu ropa y vestidos estén limpios, de manera que ninguna cosa sea suzia, de las que en tu persona tuvieres: y si fueres muy pobre, pide prestada alguna ropa."22

Es decir: una cosa son la humildad y la pobreza, valores indudables para un franciscano, y otra muy distinta el descuido en el atavío y la suciedad. Cuando menos, para disponerse a recibir a Nuestro Señor en el Santísimo Sacramento, resulta condición indispensable, simbólica además, la buena apariencia exterior.

$21 \quad I b ., 4^{\circ}$ mandamiento de Dios, f. 30.

$22 \mathrm{Ib}$., Aparejos para la comunión, ff. 71 y $71 \mathrm{v}$. Con respecto a esto, conviene recordar cómo para los evangelizadores su tarea no se agotaba en el solo adoctrinamiento religioso, sino que se extendía a toda una "modelación humana del indio" tendiente a hacerlo acceder a un estado de humanidad completa. Como se decía entonces continuamente: para poder ser cristianos, los naturales debían ser precisamente "hombres" en el pleno sentido de la palabra, el cual incluía su vida en "policía”, es decir, en civilización. Apuntaba el agustino Juan de Grijalva en su Crónica: "al ministerio del Evangelio siempre se debe entender la pulicía, como a la gracia se supone la naturaleza: y como entonces ni los indios la tenían, ni había otro que se la enseñasen fue todo obra nuestra". Acerca de este asunto, véase el capítulo V, "La modelación humana del indio", del libro de Pedro Borges, O. F. M., Métodos misionales en la cristianización de América. Siglo XVI, Madrid, Consejo Superior de Investigaciones Científicas. Departamento de Misionología Española, 1960, 573 pp., (Biblioteca Missionalia Hispánica, XII), pp. 203- 244. 
La existencia, en general, es concebida por nuestro buen fraile como un combate que ha de sostener el hombre, apoyado por la gracia divina merecida por la redención, contra el demonio, empeñado en hacerlo caer en falta. La vida del buen cristiano, así, es puro tiempo de lucha con el pecado, claro que contando, siempre, con el auxilio de Jesús, cuyo símbolo de su acción redentora, la señal de la cruz, es arma magnífica para usarse en el momento de resistir la tentación. Muy particularmente, es gracias al sacramento de la confirmación que recibe el católico en su alma la impresión de esa señal de la cruz, fortalecedora de su corazón y de su voluntad para la guerra diaria contra los enemigos del alma; dice, entonces, sobre esto, fray Alonso de Molina:

$\mathrm{Y}$ assimismo te deves consolar siempre en gran manera y regocijarte muy mucho soberanamente, con esta señal de la cruz. Y combatir con ella a tus enemigos: haziéndoles cruel guerra, hasta vencerlos, porque para este effecto, te es dada la fortaleza de nuestro Señor Dios (que es la soberana gracia) para que pelees esforzadamente, y rompas el esquadrón de todos tus enemigos. $^{23}$

A partir de los ya expresados puntos de partida, de tales formas de querer la vida del cristiano: ortodoxa, devota, referida por entero a Dios, se lanza el fraile baquiano a revisar las posibles formas en que pudieran ofender a la divinidad los indios mexicanos. $\mathrm{Y}$, para tal cosa, hace un repaso de todos y cada uno de los ordenamientos divinos y de los preceptos propios del catolicismo, procurando hacer recordar a su penitente las probables faltas que tuvo "en comer, en bever, en reyr, en jurar, en escarnecer, en maldezir, en murmurar, en fornicar, no emmendando mi vida: $y$ de todos los bienes que pudiera hazer, y no los hize: y de todos los males que pudiera apartar, que no me aparté de lo qual me arrepiento delante de Dios."24

23 Molina, op. cit., Confirmación, f. 93v.

24 Ib., Confesión general, f. 19v. 
Pero hay algo que debe tomarse muy en cuenta: los que trae a colación fray Alonso de Molina a través de sus páginas son los pecados posibles de los indígenas y no, de ninguna manera, todos ellos, los pecados frecuentes. Así, con respecto a cada uno de los que considera, ha de pensarse que fray Alonso piensa que, quizás, podían cometerlo los indígenas, y no necesariamente que, de hecho, fuera repetidamente consumado por ellos. No debe suponerse que cualquier pecado de los que habla Molina, por el solo hecho de hallarse mencionado en su libro, sea un pecado "típico" indígena. En un confesionario como este han de encontrarse expuestas las posibles faltas contra Dios y contra su Iglesia, sin que tal alusión indique que, efectivamente, sea su comisión caso común y corriente.

Mas, sin embargo de lo asentado en el párrafo anterior, sí puede pensarse que la continua reiterada cita de cierto tipo de pecados corresponde a una mayor frecuencia en su ocurrencia entre los naturales de la época. Particularmente, la repetida mención, al tratarse del primer mandamiento de la ley de Dios, de posibles reminiscencias paganas en la vida de los indígenas, debe ser indicio cierto de que tal era un peligro verdadero, de que no debía ser nada raro encontrar que buen número de indios ya bautizados de repente quisiera volver a alguna forma de culto a sus antiguos dioses o, cuando menos, a la práctica de ciertas supersticiones prehispánicas. La verdad es que las alusiones a probables supervivencias paganas son muy abundantes, particularmente al preguntar Molina a los lectores de su obra si han seguido en determinadas de las creencias de su gentilidad. Por ejemplo-recuérdese que los dioses precolombinos no eran para los misioneros sino el diablo mismo-: "Tienes todavía guardada alguna imagen del demonio; o sabes que otro la tenga escondida?;" ${ }^{25}$ o, tal vez "Invocaste a algún demonio, u otro le invocó delante de ti, y no le

25 Ib.,ler. mandamiento de Dios, f. 30. 
estorvaste, ni le acusaste delante de la sancta madre yglesia?"26

Asimismo, son múltiples las advertencias que se hacen sobre las creencias en los hechiceros autóctonos, llamado quizá uno de ellos "para que te echasse suertes, o para sacar algunos hechizos de tu cuerpo y para te chupar tus carnes tresquilote supersticiosamente: o le llamaste para que te descubiesse lo que avías perdido: 0 adivinó delante de ti en el agua?" ${ }^{27}$

Por lo demás, para los investigadores actuales, resulta curiosísima la enumeración que, allí mismo, se hace de los distintos agüeros de los nativos mexicanos:

Crees los sueños: o por ventura tuviste por agüeros a la lechuza, y al búho, a la comadreja, al escaravajo pinauztli, y tlalacatl, al épatl que se meó en tu casa, o a los hilos de las telarañas quando algunas vezes pasando por tus ojos, o quando te tiemblan los párpados de los ojos, quando tienes hipo, o quando estornudas? Tuviste también por agüero al fuego, quando haze gran ruydo la llama o sacaste fuego nuevo quando estrenaste tu casa? ${ }^{28}$

Y no sólo al hablar de las posibles faltas contra el primer mandamiento, referido a desconocimiento del Dios verdadero, se hace referencia a probables reminiscencias de paganismo. Incluso cuando fray Alonso realiza preguntas con respecto al pecado capital de la pereza, inquiere al hipotético penitente si, acaso, al casar a sus hijos "por ventura heziste con ellos alguna superstición de las que antiguamente hazíades poniéndolos, cabe el hogar juntos atándoles las mantas una con otra echando allí inciesnso."29

Tampoco se las tenía todas consigo el bueno de fray Alonso con respecto a que hubiera terminado definitivamente entre los indios recién evangelizados la práctica de un pecado tan horrible como el de la antropofagia; y por ello, al tratar de la gula, no

\footnotetext{
$26 I b .$, ff. 20 y $20 \mathrm{v}$.

27 Ib., f. 20v.

$28 \quad I b .$, f. 21.

$29 I b .$, Pereza, f. 98v.
} 
perdía la oportunidad de cuestionar sobre si "comiste alguna vez carne humana, o el mayz que se cozió con ella? porque esto es muy grande y espantoso pecado". ${ }^{30}$

Y no sólo había que cuidar a los feligreses de la caníbal ingestión de pedazos de prójimo crudos o adobados, sino también de otras comidas y bebidas prehispánicas de efectos embriagantes o alucinógenos muy relacionados, a veces, con prácticas religiosas, aunque ya entonces, en los tiempos posteriores a la conquista, hubieran perdido en mucho tales implicaciones sagradas o litúrgicas: "Comiste alguna vez honguillos que emborachan: o beviste aquel brevaje que llaman ololiuhqui perdiste por esto el juyzio? O por ventura comiste otras cosas que hazen salir de sentido, las quales te son vedadas, y a esta causa veniste a cometer algún pecado?"31

Aparte de las referidas advertencias especiales en contra de las posibles supervivencias paganas y de otros actos de raigambre prehispánica, resulta también interesante la alusión a algunos otros pecados que, por la manera en que son señalados en este Confesionario..., parece que se les concedía, por algún motivo, especial importancia. Con respecto a la lujuria y a las faltas en contra del sexto mandamiento, por ejemplo, resulta muy interesante cómo se procura no hacer demasiado hincapié en la descripción de ellas, pues fray Alonso sabe -ipor experiencia propia?, es la pregunta que uno, malicioso, no quisiera dejar de hacerle al casto franciscano- que, tratándose de esos delitos de la carne, más vale no menealle demasiado, pues quizá de su mera especificación pudieran al lector surgirle tentaciones sobre la materia. Y, así, casi no hace más que llamar la atención del que se va a confesar sobre si cometió alguno de ellos, recomendándole por lo demás "estar muy sobreaviso acerca del traer a la memoria los deleytes carnales, para que no te detengas en ellos, porque

$30 \quad I b .$, Gula, ff. 82 y $82 \mathrm{v}$.

$31 \quad I b .$, f. 82. 
no te tornes otra vez a ensuciar". ${ }^{32} \mathrm{Y}$, sin hacer mayor enumeración de las posibles formas de ofender a Dios con caídas de ese tipo, sólo le hace acordarse, en general, "de las vezes que te amancebaste, o adulteraste, o si cometiste otro qualquier pecado no digno de nombrar con el cual te ensuziaste a ti mismo". ${ }^{33}$

La referencia de fray Alonso a la embriaguez de los indios, muy desarrollada en la época, resulta bastante gráfica, y le hace llamar la atención al posible penitente :i, “por ser tú vicioso en bever vino; andas de taverna en taverna: y por todos los lugares donde se vende el dicho vino". ${ }^{34}$

La atención que se presta al cumplimiento del séptimo mandamiento, el de "no hurtarás", es muy cuidadosa, reflejo del prejuicio de pobreza propio de los discípulos de San Francisco. Un simple ejemplo del escrúpulo antimercantil del padre Molina es éste de los cuestionamientos que hace a los vendedores de tamales, por lo demás curiosísimo porque se refiere a una práctica artesanal de la cocina nacional. Escritos hace más de cuatrocientos años, parecen estar dirigidos a cualquiera de las tamaleras actuales que ofrecen su guiso afuera de una panadería o a la salida del metro: "Y tú que vendes tamales, quizá no les echaste mucha massa, y les echaste muchos frisoles dentro, o los embolviste con muchas hojas de mayz, para que pareciessen grandes?"35

Así sigue la enumeración de los pecados que forma el núcleo principal del Confesionario. De cualquier modo, toda falta cometida, por grave que haya sido, puede ser perdonada por el amor de Dios, gracias a la mediación de Jesucristo. Lo único necesario para obtener la remisión de las ofensas a Dios es el verdadero arrepentimiento de ellas. Sólo existe una circunstancia en la que no es posible alcanzar el perdón: cuando se desconfía o desespe-

Ib., Amonestación, f. 11.

33 Ibidem. El subrayado es mío.

34 Ib., Sentido del gusto, f. $102 \mathrm{v}$.

$35 I b ., 7^{\circ}$ mandamiento de Dios, f. $39 \mathrm{v}$. 
ra de la misericordia de Dios, cuando se pierde la confianza, precisamente, en que Dios puede y quiere absolver al cristiano de todas sus faltas. Este es el que, en teología, se llama pecado contra el Espíritu Santo, al cual se refiere así fray Alonso de Molina hacia las páginas finales del libro que se comenta:

O por ventura alguna vez, con el enojo que tenías, te deseaste la muerte quando no se hizo lo que deseava tu corazón, o quando no se te hizo honra, o no te dieron lo que procuravas alcanzar: o quando te sucedió algún gran desastre y aflición por razón de la qual dixiste, ioh si nunca oviese nazido en este mundo, o si fuese en breve mi fin!? Y a esta causa determinadamente propusiste de te ahorcar, o de te despeñar, o de te matar con ponzoña, y de morir en tus pecados? Porque este género de pecado, es sobremanera espantoso: y excede a los demás peccados abominables, por quanto tú a ti mesmo empides y estorvas la salvación, por no querer dexar tus pecados, ni hazer penitencia dellos (pues mediante ella, se alcanza la salvación y se perdonan todos los pecados) y tú no hazes sino menosprecialla. Y por no tener tú esperanza, en nuestro único Dios, todopoderoso, y por menospreciar y no curar de su grande misericordia, impides a ti mismo, y te privas de la sobredicha misericordia, de nuestro señor Dios: quando cotejas tus pecados, o los antepones o aventajas a la misericordia de Dios. Y este se llama y nombra desatino grande: conviene a saber, quando dizes, ciertamente mis pecados son muy grandes, y no es tan grande la misericordia de Dios. ${ }^{36}$

Nótese bien cómo aquí lo imperdonable no es la ira contra uno mismo ni el mero suicidio - pecados contra el quinto mandamiento- sino la desesperación en el amor de Dios y la desconfianza en las promesas divinas de perdón para los arrepentidos.

Como es natural en un confesionario, parte muy importante del contenido de éste se refiere a la grandeza del sacramento de la penitencia y a exaltar a ésta como el medio por el cual ha de alcanzarse de la divinidad la gracia y la remisión de las faltas cometidas contra ella misma. Claro que, para que tal hecho se produzca, lo primero que se necesita es el auténtico dolor de corazón del que quiere acercarse al confesionario, y el acto de ma-

$36 I b .$, Esperanza, ff. 107 y $107 v$. 
nifestar, de viva voz, los pecados ante el cura: "porque es la voluntad de nuestro señor Dios que tú mismo los digas y declares, para que te humilles, y avergüences: y para que por esta tu humildad merezcas el perdón de tus peccados". ${ }^{37}$

Muy claramente explica fray Alonso el sentido del sacramento de la penitencia y cómo, a partir del arrepentimiento de las faltas cometidas, es que han de expresarse éstas verbalmente ante el sacerdote que funge como representante de Dios, para que conceda la absolución, por supuesto que condicionada a que el que se confiesa de veras procure en lo posible reparar los daños consecuencia de sus culpas; y dice así el prólogo del Confesionario mayor:

y deste tal arrepentimiento tuyo, y pena quanto más: procede tu confesión con la qual declaras y manifiestas todas tus maldades (ante el sacerdote lugarteniente de nuestro señor Dios) y assí pagas y restituyes todo lo que levías restituyr y pagar, y luego te aplacas, y aplacas a los otros tornas lo ageno a su dueño, y la fama a quien la quitaste, y con la penitencia pagas y restituyes por todas tus culpas y peccados. ${ }^{38}$

Explica también el autor cómo, antes que otra cosa, lo que inste al fiel a acogerse a la confesión ha de ser el amor de Dios, el deseo de agradarle, obedecerle y honrarle; la esperanza de la salvación y el temor al castigo eterno sólo pueden ocupar un lugar secundario entre los motivos que lo lleven a buscar el perdón de las culpas en el sacramento:

Y no te has de confessar principalmente, por te librar y escapar del infierno, o por merecer el favor y ayuda de tu ánima y de tu cuerpo: o por yr a gozar de la gloria y bienaventuranza del cielo: mas principalmente te has de confessar, para complazer, agradar, obedecer y honrar a un solo y verdadero Dios. $^{39}$

37 Ib., Amonestación, f. 15.

38 Ib., Prólogo, f. 5.

$39 \quad I b .$, Amonestación, ff. $13 \mathrm{v}$ y 14. 
Por lo demás, requisito indispensable para una buena confesión es el propósito de enmienda firme, la voluntad de que, de veras, no se volverá a caer, el estar dispuesto a "no cometer otra vez ni hazer algún peccado, y de nunca más offender, ni enojar a tu Dios y señor verdadero." $" 40$

Si se han cumplido todas las condiciones señaladas -arrepentimiento verdadero, examen de conciencia a fondo, expresión de todos los pecados, fervientes deseos de enmienda y cumplimiento de la penitencia impuesta-, no cabe duda de que Nuestro Señor se dignará perdonar a quien de corazón se acercó a Él implorando volver a su gracia. Son muy hermosas las frases en las que, comparando la acción de Dios con la del médico, hace agradecer a su Señor al fiel que se ha confesado, quien ha quedado curado de los terribles achaques y ruinas de su alma en que lo sumiera su apartamiento del Creador:

O así como si oviera estado muy enfermo, lleno de hinchazones y apostemas, por los mis pecados, y quedasse agora alegre y sosegado por avérmelas vos perdonado abriendo y rebentando mis hinchazones, y echando fuera la materia y podredumbre, con la qual estavan atormentadas encenegadas y muy emponzoñadas todas mis llagas, curándolas maravillosamente, porque assí lo siente mi espíritu, delante vuestro acatamiento que los mis pecados assí como unas abominables y espantosas materias, las quales con mi confessión han rebentado: y han salido de las llagas de mis peccados, y han sanado las heridas dellas: porque ciertamente soys vos verdadero médico, e yo con mi confessión he puesto ante vuestra magestad, todos mis graves y espantosas dolencias y enfermedades, de las quales por vuestra virtud y misericordia he quedado libre y sano, y muy consolado, alegre y lleno de riquezas, por vuestra bondad, que soys mi salud, y soberano médico, en quien tengo mi esperanza $[\ldots]^{41}$

El compromiso del hombre es vivir totalmente hacia Dios, referido a Él. De allí el pecado que significa olvidar tal cosa, perder de

$40 I b .$, f. $16 \mathrm{v}$.

41 Ib., Oración final del penitente, ff. 119 y $119 \mathrm{v}$. 
vista que sólo Dios, el Creador, puede dar sentido a la vida personal. Pero, consecuencia de ese amor absoluto al Señor, de esa caridad, es la preocupación y el compromiso con los demás hombres. Así, por ejemplo, no sólo es pecado dejar de cumplir con los deberes religiosos, sino impedir que los cumplan los otros; pregunta Molina: "Estorvaste a alguno, que no oyese missa, ni la palabra de Dios, (en las fiestas solemnes) por te ocupar en tus recreaciones, juegos y pasatiempos?"42

Y también es obligación del cristiano cooperar al sostenimiento de sus hermanos necesitados, los pobres y los ancianos. Por eso resulta gran ofensa a Dios dejar de trabajar y entregarse a las diversiones y pasatiempos si por ello se descuida el mantenimiento no sólo de los seres más allegados, sino también de otros miembros de la comunidad que no pueden valerse por sí mismos. La pereza, entonces, es gran pecado no tanto porque implique ceder al peso de la comodidad y de la materia sino, principalmente, porque significa desatención de los deberes de ayuda para con el prójimo:

... y a esta causa propusiste y determinaste de perder el tiempo, y de emplearlo en plazeres y juegos, y en ser perezoso: y de andarte por las plazas: y por otros lugares, hecho vagamundo por no te ocupar ni trabajar en lo que te era necessario al mantenimiento de tu persona: y al de tu muger, y hijos, no procurando con tu industria, alguna cosa con que socorrieses a los pobres, que ya no pueden trabajar: ni tienen fuerzas corporales: y son ya viejos cansados: ni tuviste qué ofrecer y presentar delante nuestro señor Dios: en su casa y templo (assí como eres obligado). ${ }^{43}$

\section{LA RELIGIÓN CRISTIANA A TRAVÉS DEL CONFESIONARIO MAYOR}

Partiendo de las preguntas a quien realiza su examen de conciencia, Alonso de Molina realiza una amplia revisión de lo que es

Ib., Pereza, f. 98. 
toda la religión católica, si no tanto en la parte doctrinaria, sí cuando menos en la práctica, en lo que toca a la forma de vivirla adecuadamente. Así, hay allí alusiones a todos los preceptos a cuyo cumplimiento debe atender el fiel cristiano: mandamientos de Dios y de la Iglesia, obras de misericordia, virtudes cuya práctica ha de procurarse; asimismo, se explican en el libro los pecados "mortales" -los que en la actualidad más bien se conocen como "capitales"-, que son aquellos que, por su frecuencia y gravedad, más cuidado exigen para ser evitados. En esa regla de buena vida que es la obra estudiada, viene también el análisis de las ofensas a Dios que se pueden cometer en el mal uso de los cinco sentidos corporales -vista, oír, gusto, oler y tacto- y de las tres potencias del alma -entendimiento, voluntad y memoria-.

Existen en el escrito del padre Molina, además, notas bastante amplias sobre cinco de los siete sacramentos de la Iglesia: confesión, bautismo, matrimonio, comunión y confirmación; algo se habla de la extremaunción, y del único que no se trata en absoluto es de la ordenación sacerdotal. Esto resulta muy notable, pues nos hace referencia a la condición de neófitos que conservan los indígenas a través del tiempo. ${ }^{44}$ En realidad, a partir de lo que en el Confesionario se trata de los diferentes sacramentos, puede deducirse toda una teoría acerca de cómo habrían de apro-

Con respecto a la manera en que a través del tiempo conservaron los indígenas americanos su carácter de neófitos que, entre otras cosas, les impedía acercarse a la recepción de las sagradas órdenes, véase el artículo de Delfina López Sarrelangue "Mestizaje y catolicismo en la Nueva España", en Historia mexicana, México, El Colegio de México, v. XXIII, no. 1, julio-septiembre de 1973 (89), pp. 1-42. La autora, allí, llega a la conclusión de que las trabas impuestas a indígenas, mestizos y criollos para acceder al clero eran resultado más de una "prudente reserva" provocada por ciertas experiencias que clel orgullo o el exclusivismo, toda vez que, para ella "en todo caso, hay que reconocer que el proceder eclesiástico se sostuvo siempre en el respeto a la dignidad humana y en la decidida voluntad de que, para todos, en las Indias se abriesen las puertas de la "Casa del Padre"" (Ib., p. 42). 
vechar éstos a los indígenas, según los misioneros franciscanos. Un indio, para ellos, debía bautizarse y confirmarse, para ser cabal cristiano, y casarse para vivir familiarmente de acuerdo a esa religión a la que se había adherido; convenía que se confesara a menudo, para limpiarse de las impurezas en que incurriera en su vida, y antes de morir recibir la unción extrema, a fin de prepararse para comparecer en juicio ante su Dios; podía, en fin, recibir el santísimo sacramento de la comunión, claro que tras una adecuada preparación para ello. Sólo para que se hiciera sacerdote era para lo que se le ponían reparos, de modo que, a lo largo de todo este libro que debía leer para aprender a vivir su religión, no se halla la más mínima alusión, ni siquiera, a la importancia y dignidad del estado clerical.

Por supuesto que el librito analizado no tiene ninguna pretensión erudita, y que por lo tanto no puede esperarse encontrar en él una amplia cita de fuentes documentales para apoyar sus afirmaciones. Sin embargo, sí aparecen diferentes menciones a determinados textos, principalmente escriturísticos, pero también de algunos santos y de otros libros eclesiásticos. Puede resultar interesante, cuando menos para considerar cuáles autores eran los más conocidos y apreciados por fray Alonso, una lista de todos los autores y textos mencionados dentro de las páginas del Confesionario mayor. Es la siguiente, sacada de las referencias que vienen en los márgenes del volumen:

Antiguo testamento

Salmos (2 citas)

Proverbios (2 citas)

Rey Ezequías (1 cita)

Job (1 cita)

Nuevo testamento

Evangelios

San Mateo (4. citas)

San Lucas (1 cita)

San Juan (1 cita)

Hechos de los apóstoles (2 citas)

Epístolas de San Pablo 
Romanos (4 citas)

Filipenses (1 cita)

Efesios (1 cita)

Epístola de Santiago (2 citas)

\author{
Santos \\ San Agustín (3 citas) \\ San Gregorio (1 cita) \\ San Bernardo (1 cita) \\ San Francisco (1 cita)
}

Otros textos eclesiásticos (3 citas)

Hay, aparte, una referencia al emperador Constantino, a quien "le fue mostrada la admirable señal de la cruz". ${ }^{4.5}$

También es muy sintomático, para darse cuenta de la religión que quiere transmitir fray Alonso de Molina a sus lectores, realizar un análisis de los grabados que ilustran el tomo. Éstos resultan, además de bellos, muy claros y expresivos de una forma de entender el catolicismo y de tratar de enseñarlo a unos hombres y mujeres recién convertidos.

En total, son treinta los grabados que allí aparecen, pero como siete de ellos se encuentran repetidos (uno dos veces), son en realidad veintidós diferentes. Los enlisto a continuación:

Antiguo testamento (1)

Moisés en el Sinaí, recibiendo los 10 mandamientos

Escenas de la vida de Jesús (13) (María aparece en 3)

María con el Niño Jesús en brazos

Presentación de Jesús en el templo, por María y José

El Niño Jesús enseñando en el templo

Jesús, ya adulto, predicando a los doctores de la ley judía (repetido)

Jesús expulsando a un demonio, durante su vida pública

Jesús predicando a los judíos (repetido)

La mujer que toca a Jesús la punta de su vestido

45 Molina, op. cil., Confirmación, f. 93v. 
Jesús resucitando a un muerto

Jesús con un enfermo

Jesús con una mujer, que está de rodillas ante Él

Jesús con los niños

La Última Cena

El Calvario: Cristo en la cruz; a su lado, María y San Juan (repetido)

Busto de Jesús (1) (repetido)

La Trinidad (1)

Frailes franciscanos ejerciendo su ministerio misional (3)

Fraile evangelizando (repetido dos veces)

Fraile confesando (repetido)

Fraile casando a dos indígenas

El Papa con cuatro cardenales (1) (repetido)

Ancla (símbolo de la Iglesia) (1)

El demonio (1) (aparece en otros dos)

En una rápida revisión de la temática de esos grabados salta enseguida la consideración de que la figura central de ellos es la de Jesucristo, quien aparece en diferentes aspectos de su vida. La religión que se presenta en el Confesionario es eminentemente cristocéntrica. Luego, también hay varias ilustraciones referentes a escenas y personajes de la vida de la Iglesia: el Papa, las actividades de los franciscanos en México, el ancla que simboliza la seguridad en la salvación... El demonio, que es el enemigo contra el cual han de luchar los fieles a través de toda su vida, se encuentra allí representado tres veces, una de ellas en todo su horror, con garras de león, patas de cabra y ocho cabezas, pero las otras dos en actitud de retirada y derrota: una expulsado por Jesús durante su vida pública y otra huyendo de un indio que se confiesa. No se dibujan santos, salvo San Juan y San José que aparecen junto con Jesús; María está en tres ocasiones: dos con su Hijo niño y la otra al pie de la cruz. 
Pasemos ahora al estudio de algunos de los conceptos fundamentales del catolicismo, tal y como aparecen en este texto.

Ya se dijo que, allí, la personalidad humana encuentra toda su significación, adquiere toda su importancia, referida a Dios. Por sí solo, el hombre no posee nada, no merece nada; todo lo que tiene, todo lo que consigue, todo lo que hace, es gracias a su Creador. Y su obligación es reconocer tal cosa, si no desea pecar de soberbio; pregunta fray Alonso:

Pensaste quizá alguna vez, o lo tuviste assí entendido, que la hazienda que tienes: o qualquier otros bienes, que los has avido por tu industria, y que no te los dio nuestro señor Dios, ni vinieron de su mano: 0 por ventura dixiste, hámelos dado Dios, por mis merecimientos, y por ser muy digna mi persona de que Él me los diese? ${ }^{46}$

Dios es, pues, todo. Creador, redentor y vivificador del mundo y del hombre. A Él se debe todo, y a Él ha de dirigirse el completo amor de cada quien, en justa reciprocidad a lo que de Él se ha recibido. Molina resume en tres cosas las principales mercedes divinas que es preciso tener en consideración para inflamarse en amor hacia el santísimo sacramento:

La primera es, el averte hecho nuestro Señor Dios a su ymagen y semejanza: (en quanto al alma) La segunda es, el estar y morar siempre contigo, para te favorecer ayudar y consolar, y la tercera es, el considerar los grandes e innumerables beneficios, dones gracias, y misericordias, que su magestad con su gran liberalidad ha hecho, y comunicado, etc. ${ }^{47}$

La fe, la esperanza y la caridad totales debe tenerlas depositadas el hombre en el Señor, y así lo enfatiza el autor de la obra que se revisa, al realizar los cuestionamientos referentes al primer mandamiento: ${ }^{48}$

\footnotetext{
46 Ib., Soberbia, f. $77 \mathrm{v}$.

47 Ib., Aparejo para comulgar, ff. 74 y $74 \mathrm{v}$.

48 Ib., ler. mandamiento de Dios, f. 20.
} 
$F e$ : Hijo, crees verdaderamente en nuestro señor Dios, y crees todas aquellas cosas que pertenecen a su fee o por ventura alguna vez dubdaste en ellas? Esperanza: Tienes en Él toda tu esperanza, y ámasle perfectamente, de todo tu corazón, y con todas tus fuerzas, solamente por sí mismo, y porque es dignísimo de ser amado, y honrado, y digno de toda adoración?

Caridad: Hasle amado con toda tu voluntad, y hasle alabado y bendezido con tus palabras, y hasle agradado y obedecido con tus obras?

El hombre se halla en las manos de Dios y de su Providencia. Todo lo que sucede es por Él inspirado y obedece a sus supremos e inescrutables designios: las enfermedades mismas, y todas las desgracias, han de sufrirse con alegría, puesto que no son, en realidad, sino "visitas" de la divinidad. ${ }^{49}$

Al fin del Confesionario, como acción de gracias del penitente que ya ha recibido el don de la absolución, coloca su autor una hermosa oración, cuyas frases finales constituyen el siguiente himno en homenaje a la majestad divina:

Seays pues vos solo señor universal por siempre sin fin, que bivís eternalmente, y bendigan a vos alaben y maravíllense de vuestra grandeza todas las vuestras criaturas, acá en este mundo, y allá en el cielo, porque verdaderamente pertenecen a vuestra magestad, todo loor y bendición: toda claridad y sabiduría, toda virtud, bondad y fortaleza, y es muy justo, que todo hombre, os alabe y bendiga: porque soys digno, y pertenece a vos el ser perpetuamente reverenciado, y adorado de todos nosotros, criaturas y hechuras de vuestras manos: y que os amemos, queramos obedezcamos, y hagamos vuestra voluntad, y que con toda nuestra virtud y fuerzas, nos maravillemos y admiremos de vuestra grandeza y magestad. Amén. ${ }^{50}$

Y Dios es Santísima Trinidad: Padre, Hijo y Espíritu Santo. Así, tanto al iniciar su trabajo" como al colocar la "Cabeza de testa-

49 Se pregunta así, al referirse a la ira (Ib., fi. 81 y 81v): “Quando nuestro señor Dios: te visitó con alguna grande y grave enfermedad, por ventura no la padeciste con alegría, o quizá te amohinaste y te enojaste?" El subrayado es mío.

50 Ib., Oración final del penitente, ff. $120 \mathrm{v}$ y 121 .

51 Ib., f. 3 . 
mento" 52 , realiza fray Alonso una invocación a las tres personas divinas. En particular, es la segunda de ellas la que resulta nombrada más veces a lo largo del texto, puesto que es el Hijo, Jesucristo, quien mediante su encarnación reveló a los hombres la verdad divina y quien fundara la iglesia que, por la obra de su propia redención, es el lugar en el cual encuentran los hombres su salvación. De todos modos, quizá por un cierto temor a que los indios tomaran por tres dioses distintos a las tres personas, no son muchas las alusiones específicas a cada una. No se insiste gran cosa en la diferenciación de sus "funciones" propias, y sólo se recuerdan algunas circunstancias particularmente importantes de la vida de Jesús; y esto, más en las representaciones gráficas ya comentadas que en el texto mismo. De cualquier modo, a través de todo el libro se observa una preocupación muy viva por mantenerse siempre apegado a la ortodoxia, y tampoco se podría acusar a Molina, ni mucho menos, de intentar soslayar el misterio de la Trinidad, punto de doctrina cuya aceptación siempre ha sido motivo de polémica.

Fuera de alguna citas del Antiguo Testamento y del grabado que representa a Moisés en el acto de recibir las tablas de la Ley, no hay en el Confesionario referencias a la historia sagrada, así como tampoco a la eclesiástica de después de Jesucristo, si se exceptúa la que se hace de algunos escritos de San Agustín, San Gregorio, San Bernardo y San Francisco. Resultó natural que este último varón, fundador de la orden a la que pertenecía Alonso de Molina, se mencionara en el libro de vez en cuando.

En la "Confesión general" que se reza antes de la exposición de los pecados por parte del penitente, se alude a que tal acto habrá de llevarse a cabo delante de Dios Nuestro Señor, así como de "sancta María, siempre virgen y de sant Pedro y de sant Pablo, y de sant Miguel Archángel y de sant Francisco, y de todos los

52 Ib., Cabeza de testamento, f. 61. En este lugar, además, se ha colocado un grabado de la Trinidad. 
sanctos de la corte del cielo". ${ }^{53}$

Asimismo, en los cuestionamientos sobre el primer mandamiento se trata de la honra debida "a la cruz de nuestro redentor Jesuchristo, y a su ymagen: y a las ymágenes de los sanctos, quando pasas delante dellas" ${ }^{54} \mathrm{Y}$, en igual sitio, se insiste en la pregunta sobre si "tuviste reverencia al sanctíssimo Sacramento, y a sancta María madre de Dios, y a todos los sanctos?"55

Tocante a la dulía propuesta en este libro, conviene mencionar que las vigilias en cuyos días debían abstenerse de comer carne los naturales eran las de las fiestas que se enlistan: San Matías, San Juan Bautista, San Pedro y San Pablo, Santiago, San Lorenzo, la Asunción, San Bartolomé, San Mateo, San Simón y San Judas, Todos los Santos, San Andrés y Santo Tomás. ${ }^{56}$ Como se ve, aparte del Precursor y del importante mártir de las persecuciones Lorenzo, así como la principal fiesta de la madre de Dios -Nuestra Señora de Agosto-, todos los demás son apóstoles y predicadores del Evangelio. Resultó natural que, para una iglesia que estaba surgiendo gracias a la predicación, se escogiera como especiales patrones, precisamente, a quienes habían sobresalido heroicamente en su celo misionero.

La obra comentada hace mucho énfasis en el lugar de la Iglesia católica como mediadora entre la redención y los hombres, sobre todo en cuanto a su función de dispensadora de los sacramentos. ${ }^{57}$ Por lo demás, la sola incorporación de los cinco mandamientos de "nuestra madre sancta" la Iglesia al análisis de aquellos ordenamientos que han de cumplirse, indica sobradamente el primerísimo lugar que se otorga a esa institución y a sus

Ib., Confesión general, ff. 19 y $19 \mathrm{v}$.

Ib., ler. mandamiento de Dios, f. $21 \mathrm{v}$.

5 Ibidem.

$56 I b .$, Abstinencia de los naturales, ff. $67 \mathrm{v}$ y 68.

57 Así, se hace hincapié en que el sacerdote que confiesa no otra cosa que "el lugarteniente de nuestro señor Jesucristo". Ib., Amonestación, f. 16. 
disposiciones en materia de dogmas y de moral. Tales ordenamientos han de ser sabidos de coro, y si los menosprecia -se le advierte a quien realiza su examen de conciencia- "cometerás grave pecado, el qual se llama mortal, y serás eternamente maldito, y desechado, e yrás a ser atormentado para siempre en el infierno". 58

El indio, como cualquier otro católico, tiene ciertas obligaciones con la Iglesia a la cual pertenece; entre ellas, la de diezmar de sus ganancias y beneficios, por supuesto que "según y de la manera que en cada pueblo y ciudad, lo ordena y manda el sancto Padre, el qual mide y tassa prudentemente, y declara lo que ha de dar, y diezmar, y la cantidad que cada uno ha de ofrezer por diezmo, (ante nuestro señor)". ${ }^{59}$

Estos neófitos ameriçnos pertenecen ya, por el bautismo, a la comunidad eclesiástica, al "cuerpo místico" formado por todos los cristianos. En cuanto a esta idea, tiene mucho interés lo que se dice al hablarse del Jubileo, sobre que ha de rezarse mucho ante Dios porque la paz reine entre todos los príncipes cristianos:

... supplicando ahincadamente a Aquél mediante el qual bivimos, que tengan amistad y paz: y se aplaquen aquellos grandes señores (los quales se llaman reyes christianos) para que tengan amor los unos con los otros, y para que rijan y goviernen bien sus reynos, y bivan en toda paz y sosiego de manera que no haya guerra entre ellos, ni se den pena y afflicción: ni se maltraten los que son cristianos, y fieles de nuestro señor Jesuchristo. ${ }^{60}$

En este pacifismo, tan de tipo franciscano, quizás pudieran descubrirse atisbos milenaristas o utopistas. Pero no es ahora el momento de realizar, con toda la profundidad que requeríía, un amplio estudio sobre temas tan inquietantes, que por lo demás ya han merecido recientemente la atención de varios autores.

\footnotetext{
$58 \quad I b .$, Mandamientos de la Iglesia, f. 65.

59 Ib., $5^{\circ}$ mandamiento de la Iglesia, f. 76.

co Ib., Jubileo, f. 96.
} 
A través de las páginas de este libro aparece la noción de la necesidad de los sacramentos para alcanzar la salvación. De todos y cada uno se hacen interesantes comentarios; como ya se dijo, sólo del orden sacerdotal no hay allí explicaciones.

Del primer sacramento que se habla es, naturalmente, la confesión, precisamente el que da sentido al libro.

Se cita con mucha insistencia la importancia el bautismo como puerta de ingreso a la Iglesia. Había que resaltar mucho esto, como salta a la vista, ante quienes acababan de convertirse y a los cuales había que hacer ver la importancia del sacramento que, con el agua, habían recibido. Además, ante la escasez de ministros, se quiso dar a conocer a los ya cristianizados los requisitos y fórmulas para que cualquiera, siguiendo unos determinados ritos, pudiera bautizar a quienes -sobre todo los niños recién nacidos, sus hijos- se hallaran en peligro de muerte. Tras dar tales instrucciones, el padre Molina se refiere a la trascendencia que pudo alcanzar ese acto de bautizar a quien, si no hubiera sido por eso, se hubiera condenado irremediablemente: "Y tú, que tienes cargo de baptizar, si hizieres todo lo que aquí se ha dicho, merecerás mucho delante de nuestro señor, y alcanzarás muy gran galardón allá en el cielo: por quanto ayudaste a tu próximo, para que se salvasse, y por tu piedad alcanzó y mereció la gracia de nuestro señor Dios". ${ }^{61}$

Mientras trata de las posibles formas de pecar por pereza, lo hace nuestro autor de la importancia de otro sacramento, el de la confirmación, "maravilloso y fortificante"; si por desidia y flojera no se quiso acudir a él, apunta, "ofendiste gravemente al por quien todos biven y cayste verdaderamente en pecado mortal: y hiziste mucho mal a tu ánima". ${ }^{62}$

61 Ib., Bautizo, f. 25.

62 Ib., Confirmación, ff. 83 y $83 \mathrm{v}$. 
Quienes se confirmaron, si se salvan, en la gloria serán "sobremanera afamados y tendrán mucha honra", ${ }^{63}$ por el contrario, si se condenan, serán en el infierno particularmente conocidos por falsos y fingidos cristianos puesto que, eternamente, el confirmado "trae consigo las insignias del universal emperador Jesuchristo, dando a entender que es su verdadero soldado, y que es verdaderamente de su vando". ${ }^{64}$

También pecará gravemente quien, por "pereza y olvido", dejó de procurar el sacramento de la extremaunción; se insiste en la obligación de intentar administrar éste aun cuando no resulte posible recibirlo: "Y aunque no se te pudiera dar, tú empero eres obligado, a lo desear affectuosamente y a lo buscar y pedir. Y eres también muy obligado, de tener cuydado de tus hijos: y de la gente de tu casa, para que alcancen y reciban este tan gran beneficio". 65

Son también muy abundantes las referencias al sacramento de la comunión, a cuya preparación -"aparejo"- se dedican varias páginas. Quien comulga ha de creer que en la hostia "está allí Dios padre y Dios Espíritu Sancto, y que verdaderamente está dentro del Sarctísssimo Sacramento entera y perfectíssimamente, la sanctíssima Trinidad" ${ }^{66}$

El otro sacramento del que se trata es el del matrimonio, que es explicado como auténtico camino de salvación. Se hace mucho hincapié en los preparativos previos a la boda, y en señalar los requisitos para que ella sea legítima: "los que tienen cargo de preguntar, y escrevir a los que quieren casar, les es muy necessario, que los examinen bien y les pregunten cosas a aquellos que

$65 I 6 ., 4^{\circ}$ mandamiento de la Iglesia, ff. $69 \mathrm{v}$ y 70.

o6 Ib., Aparejo para la comunión, f. 73v. 
quisieren recebir el sacramento del matrimonio, para que no lo deshonren". 67

Parte importante también dentro de la doctrina católica es la necesidad de la práctica de ciertas virtudes, particularmente las llamadas "teologales" -fe, esperanza y caridad-, en atención a que su base de sustentamiento es Dios, a quien precisan a conocer, para confiar en Él y luego entregarse plenamente a su amor. Entre los folios 105 y 113 del Confesionario mayor inquiere fray Alonso de Molina acerca del comportamiento del cristiano con respecto a esas virtudes. Creer y esperar en el Señor -fe y esperanza en Él-quizás no requieran mayor explicación, pues la sola conversión supone ya su posesión; lo que sí requiere un cierto comentario, unas determinadas observaciones es la forma en que ha de amársele, es decir, de vivirse la caridad en Él, puesto que esta es una virtud más "activa", que implica el desempeño de determinadas obras. Después de asentar que no ha de temérsele con el terror de un mísero esclavo ante su amo, así explica nuestro fraile franciscano cómo ha de quererse a Dios, con un amor que mueva a servirlo en todo, a hacer de toda la propia vida una oración y una ofrenda a su divinidad:

... o temiste a tu Señor Dios, assí como lo hazen los esclavos, que temen a su Señor, y hazen lo que les manda y le obedecen, porque no los castigue y maltrate: pues ten entendido, que te conviene mucho servir con amor, y con temor reverencial obedecer y hazer la voluntad de tu Dios y señor para que muestres ser verdaderamente hijo suyo. Porque nuestro señor Dios solamente estima y tiene en mucho, lo que de tu motivo y de tu propia voluntad y cle todo tu corazón, hazes por su respecto y por su amor. ${ }^{68}$

De acuerdo con el pensamiento de la época, sabe fray Alonso que el principal enemigo de la buena práctica de los preceptos de la religión es el demonio, ángel caído de un primitivo estado de

67 Ib., Matrimonio, ff. 45 y $45 \mathrm{v}$.

$68 I b$, Caridad, ff. 112 y $112 \mathrm{v}$. 
gracia y predilección por un pecado de orgullo y el cual, por envidia, por odio hacia quien lo castigó expulsándolo de su lado, se dedica a intentar que los hombres también pequen. Siempre, detrás de las tentaciones, descubre la presencia del diablo, ya sea en los vanos encantos del mundo y de sus diversiones:

0 por ventura oyste de buena gana los cantares y músicas vanas, y carnales, y las consejas y fábulas desonestas, y los cantares del demonio, o sus palabras y enseñamientos nocivos, con los quales pervierten, y engañan las gentes, los hechiceros y hechiceras, los viejos y viejas diabólicos, que no creen en nuestro señor, y se baptizaron fingidamente; ${ }^{69}$

o bien, más específicamente en el caso mexicano, a través de las enseñanzas engañosas de los dioses falsos de la gentilidad. Además de las asechanzas diabólicas por intentar hacer que los indígenas no perseveraran en su nueva fe, volviendo plenamente a sus prácticas y devociones prehispánicas, el demonio, pensaban Molina y los demás misioneros de la época, se esforzaba en tentar a sus súbditos recién perdidos -que no eran para ellos otra cosa los naturales últimamente convertidos- haciéndolos practicar las hechicerías y demás supersticiones propias de los tiempos anteriores a la evangelización. Se le pregunta, pues, al presunto lector del Confesionario:

Ofreciste por ventura alguna vez tu ánima al demonio engañándote él, y escarneciendo de ti, con sus embaymientos o tú de tu voluntad te engañaste aprendiendo las palabras del demonio, para hechizar a los otros, o para provocar las mugeres a luxuria o para encantar, o para conjurar al granizo o para adivinar en agua, o echando suertes? ${ }^{70}$

La principal arma para defenderse de las provocaciones de Satán -asienta repetidas veces fray Alonso- es la recepción de la con-

69 Ib., Sentido del oír, f. 102.

$70 \quad I b .$, Fe, f. 106. 
firmación, la cual ayuda al cristiano, "fortalece su corazón, e le da fuerzas para vencer perfectamente todos los ardides de guerra del demonio". ${ }^{71}$ Pocas páginas después, se insiste en lo necesario que es el dicho sacramento para sostener victoriosamente la lucha contra el Malo en que consiste la vida:

\begin{abstract}
... mas cuando nos es dada la confirmación, recibimos, (mediante ella) mucho mayor gracia [que con el bautizo], y muy mayor esfuerzo y fortaleza, para pelear, sobrepujar y vencer todas las tentaciones y ardides del demonio y del mundo, por quanto bivimos en continua batalla como está escripto en la sagrada escriptura: Militia est vita hominis super terram (Job, 7), quiere decir: Que es batalla la vida del hombre, sobre la tierra. ${ }^{72}$
\end{abstract}

Aparte de todas las creencias, principios y valores del catolicismo en general a los cuales se refiere la obra, fue natural que fray Alonso de Molina, al intentar enseñar a los indígenas su propia religión, en la cual él creía radicalmente, al grado de haber querido dedicar toda su vida a predicarla, a darla a conocer a unos hombres que, por haber sido convertidos recientemente, necesitaban todavía adentrarse en los entresijos de ella; fue natural, digo, que deseara dar particular importancia a determinados aspectos a los cuales hacían especial énfasis los miembros de la orden a la que pertenecía. Los frailes menores, desde el momento mismo en que fueron establecidos por San Francisco, habían querido hacer el centro mismo de su vocación la aplicación a su vida de uno de los que, para ellos, eran los valores más específicos del cristianismo, según la predicación del Redentor: la humildad, en los dos sentidos de la palabra: material - pobreza, desprendimiento de los bienes terrenos- y espiritual -oposición a la soberbia, a la complacencia en la propia personalidad-.

Ejemplo de las referencias del Confesionario... a este énfasis franciscano en los altísimos valores de la humildad - "los últimos

$71 \quad I b$., Confirmación, f. 88.

$72 \quad I b .$, f. 91. 
serán los primeros", "el que se humille será ensalzado", "haceos pequeños como los niños" - son los amplios comentarios que merecen las posibles maneras de pecar en contra del séptimo mandamiento: "no hurtarás". Ante la enumeración de los múltiples engaños que pueden hacer los comerciantes en sus tratos y mercaderías, salta enseguida a la memoria el poco aprecio del Poverello de Asís por esa profesión, la de su padre, ni más ni menos, aquella a la que el santo renunciara espectacularmente en el momento de su conversión. Así, verbigracia, no puede fray Alonso menos que recelar de que quien vende ese fruto haga la trampa de revolver "el buen cacao con el malo, para que todo se emplease y vendiese, engañando a las gentes". ${ }^{73}$ Para esta manera franciscana de entender las cosas, la función de las riquezas, la causa por la que las entregó Dios a algunos hombres fue para que ellos las repartiesen a quien hubiera necesidad de una parte de ellas; por eso es tan tremendo pecado el goce egoísta en los bienes materiales. En fin: ¿qué mayor culpa si, "por esta tu avaricia y cobdicia, se pudrió emmoheció y dañó, mucha parte de tu hacienda, con la qual pudieras merecer mucho y ser salvo: si la dieras y repartieras?"74

La riqueza bien entendida -se comprende, usada sólo para atender a las necesidades del prójimo- puede ser incluso hasta escalón para el cielo; mal disfrutada, mal habida, mal retenida, resulta resbaladilla directa para el infierno.

En cuanto a la humildad con respecto a la propia valía individual, son también notables las advertencias molinescas en contra de la soberbia, sobre todo cuando repercute en faltas contra la caridad. Así, por ejemplo, al preguntar a quien va a confesarse: "O quizá por tu soberbia, menospreciaste los pobres, huérfanos y

73 Ib., $7^{\circ}$ mandamiento de Dios, ff. $37 \mathrm{y} \mathrm{ss.}$

74 Ib., Avaricia, f. 80. 
enfermos, por los deffectos naturales que tenían: o los escarneciste, o les diste alguna pena y aflición?"75

Humildad, decía santa Teresa, es conocimiento de la propia valía, de la realidad personal. Así, debe servir para poner coto al exagerado deseo de ciencia, de querer conocer misterios escondidos a las capacidades y a las necesidades de cada quien. El que examina su conciencia en búsqueda de las ocasiones en que pudo faltar a su Dios, sugiere el padre Molina, debe recordar si "Quisiste por ventura, y deseaste por tu sobervia: saber algunas cosas arduas y dificultosas, las quales no tenías obligación de saberlas ni de entenderlas?"

Para la Salvación PERSonal del indíGena

El Confesionario mayor de fray Alonso de Molina se dirige a los indios mexicanos ya cristianizados, a poco menos de medio siglo de consumada la conquista del país. De todos modos, siempre se nota el recelo del autor del libro acerca ce que, en realidad, no todos aquellos que pretenden confesarse sean ya cristianos efectivos, realmente bautizados y conscientes del significado de su incorporación a la Iglesia de Cristo; así, les inquiere: "Eres baptizado, recebiste de todo tu corazón el agua de Dios que se dize baptismo: O por ventura lo tuviste por cosa de burla, o lo recebiste siendo forzado, y te llevaron arrastrando a que te baptizases?". ${ }^{77}$ Igualmente, se interesa por preguntar a sus lectores si tienen ya una cierta experiencia del sacramento que intentan ahora recibir: "Haste confessado otra vez o es esta primer vez que te confiessas? ${ }^{78}$

\footnotetext{
75 Ib., Soberbia, f. 79.

76 Ibidem.

77 Ib., f. 18.

$78 I b .$, f. $18 \mathrm{v}$.
}

$108 \quad$\begin{tabular}{cllllllllllllll}
\hline & A & A & E & E & I & D & O & S & C & O & P & I & O
\end{tabular} 
E insiste mucho en cuestionar, a estos cristianos nuevos, con respecto a los diversos sacramentos que pueden haber ya tomado, si cumplieron con todas las condiciones necesarias para ello; muy especialmente, si es que no han querido hacer dos veces aquellos que sólo se pueden realizar una: "Baptizaste por ventura dos vezes, o recebiste dos o tres vezes la confirmación: o casástete en dos o tres partes, y son aún vivas todas aquellas con las quales te casaste por la yglesia?"79

Para ayudar en su confesión a estos nuevos cristianos que no hablan español, para hacerlos caer en la cuenta de las posibles veces en que quizás faltaron a sus deberes novedosos de católicos, es para lo que ha decidido fray Alonso redactar esta obra que se analiza. Simultáneamente, puesto que ésta la ha compuesto bilingüe, espera que también sirva para que los misioneros acaben de aprender el náhuatl, particularmente las palabras y expresiones de difícil traducción. Así se refiere nuestro buen fraile baquiano a las motivaciones de lingüista que lo llevaron a ponerse a trabajar en el libro:

... considerada la obscuridad y difficultad de la dicha lengua destos naturales, y phrases de hablar, suyo muy differente en muy muchos casos de nuestra lengua Castellana y Latina [...], para lumbre e ynstrucción de los ministros desta Yglesia, y utilidad de los naturales, y los dichos Ministros sepan los proprios y naturales vocablos, que se requieren para preguntar y entender en la administración del Sacramento de la Penitencia. ${ }^{80}$

Él, fray Alonso de Molina, que desde muy niño convivió con los indígenas, ha podido aprender con especial perfección el mexicano, lo que le ha servido para doctrinar durante toda su vida, adentrándose cada vez más en el idioma; por eso decidió componer sus trabajos:

79 Ib., ler. mandamiento de Dios, f. 2lv.

80 Ib., Epístola nuncupatoria, f. 2. 
Y porque desde mi tierna hedad: nuestro Señor fue servido de me dar alguna noticia desta lengua Mexicana: y en ella he predicado muchos años, y administrado los Sacramentos (máxime el de la penitencia) a esta gente, (porque no sea reprehendido del pequeño talento comunicado) quise tomar este trabajo, y hazer estos dos Confesionarios. ${ }^{.1}$

Según cuenta Molina a los naturales mexicanos, ellos son los destinatarios de su Confesionario mayor; particularmente, a cada uno de los posibles consultantes le explica que éste lo ha escrito "para ti, con el cual yo te favorezca algún tanto, y ayuda a salvar a ti que eres cristiano, y te has dedicado y ofrecido a nuestro señor Jesu Christo, cuyo fiel y creyente eres, tú que tienes la sancta fee católica". ${ }^{82}$

Naturalmente que, en concepto de los frailes que los han evangelizado, que han dedicado sus esfuerzos a hacerlos de veras cristianos, los indios ya bautizados son católicos cabales, con la obligación de cumplir todos los deberes que les impone su nueva religión y, también, por supuesto, con la facultad de vivirla plenamente, recibiendo todos sus sacramentos y ejercitándola por completo en todo lo demás. Sin embargo, la verdad fue que los frailes y sacerdotes que se ocuparon de ser los pastores de este nuevo rebaño de la Iglesia de Cristo, quisieron conferirles dentro de ella una situación especial, que los dejó sujetos a una condición un tanto de niños bajo la tutela de un paternalismo que, de algún modo, tal vez no les dejó desarrollarse por completo como cristianos íntegros.

Se trataba, por ejemplo, de que todo su cuidado espiritual quedara bajo el encargo de sus propios misioneros, de aquellos que sabían su lengua y entendían sus problemas; para confesar-

81 Ib., f. 2v. Estos "dos confesionarios" son, como ya se apuntó en la nota 2, el mayor, aquí analizado, y otro menor, "pequeño y breve, para tu confessor". Ib., Prólogo, f. 6v.

Ibidem. 
se, verbigracia, habían de acudir "a un solo sacerdote, conviene a saber al que entiende bien vuestra lengua, y al más prudente y sabio". ${ }^{83}$

Este pastor de sus almas sabía de su situación especial, de sus limitaciones para el cumplimiento de sus obligaciones religiosas, las cuales por lo demás, en determinados aspectos se hallaban mitigadas. Así, los días de ayuno y de abstinencia de carne para ellos eran mucho menos que los de los españoles; en el Confesionario aparece la lista de tales jornadas. Claro que, si querían, podían ayunar y dejar de comer carne cuando les aconsejara su devoción, además de los días de su obligación. ${ }^{84}$

Podía darse el caso, por ejemplo, de que la penitencia que les impusiera el sacerdote después de confesarlos les pareciera de difícil cumplimiento; entonces, los instaba el padre Molina a manifestarlo así al confesor, pidiéndole se las conmutara por otra de más fácil ejecución; les recomienda, pues, decirle, en ese caso: "Padre mío por razón de mi enfermedad, o por los grandes negocios y trabajos que tengo no podré hazer lo que quieres, ruégote que tengas piedad de mí, y que yo dé alguna limosna a los enfermos y ciegos socorriéndoles en necesidades, o que yo sirva algunos días personalmente en el hospital, etc." $\$ 5$

De cualquier modo, atendiendo a lo poco firme que, a veces, le parece a Molina la instrucción religiosa de estos indios nuevos en el cristianismo, siempre que puede insiste en la conveniencia de continuar con ella. Así, antes de casarlos, aconseja al sacerdote que va a oficiar en la boda que les mande, previamente a contraer, "que aprendan la doctrina Christiana, de manera, que la sepan de coro". 86

83 Ib., Amonestación, f. 14v.

8. I Ib., $2^{\circ}$.mandamiento de la Iglesia, f. $66 \mathrm{v}$.

$85 I b$., Amonestación, ff. 16 y $16 \mathrm{v}$.

86 Ib., Matrimonio, f. 48. 
Dirigido en general a todos los indios, algunas de las preguntas que formula fray Alonso en su Confesionario mayor, sin embargo, están destinadas a determinados grupos de ellos en particular. Así, en varias ocasiones hace cuestionamientos precisos sobre su comportamiento a los principales y caciques, a quienes en particular inquiere acerca de si han sabido cumplir con los deberes propios de su estado; a saber: de su conducta con los macehuales que se hallan bajo su cuidado. Ejemplo de estas alusiones se encuentra en la parte relativa al 3er. mandamiento, cuando Molina aconseja al confesor: "Y si es principal pregúntele: En los domingos y fiestas descuydaste en hazer, que se ayunte la gente, en la yglesia, a oyr missa y sermón?"87

Y al tratar del séptimo mandamiento les dice, acerca de las posibles veces en que pudieran infringir ese precepto:

$\mathrm{Y}$ si fuere cacique, principal, tequitlato, o mayordomo, el que confiessa, pregúntele.

Tomaste alguna vez alguna cosa a los macehuales, que tienes a cargo, y a los que governabas? Pedísteles mantas, gallinas, cacao, etc. Las quales cosas ellos no eran obligados a darte?

Añadísteles y acrecentásteles su tributo? O tomásteles y demandásteles alguna cosa, para dársela al español, que servís, o para otro cacique, o principal (pretendiendo su amistad) y quando todos baylan, en las fiestas, por ventura pediste tributo de tortillas, o de cacao, flores, cañas de sahumerio, o esteras, etc.? ${ }^{88}$

También, en alguna ocasión, se han de formular cuestionarios específicos para mujeres; así, por ejemplo, para averiguar si es que han trabajado en "labores propias de su sexo" en los días de fiestas de guardar: "Y si es muger, la que se confiessa, pregúntele el Confesor: En los domingos y fiestas ocúpaste en hazer algo, hilas, texes, coses, o por ventura lavas la ropa?"89

Ib., 3er. mandamiento de Dios, f. 28v.

Ib., $7^{\circ}$ mandamiento de Dios, f. $41 \mathrm{v}$.

89 Ib., 3er. mandamiento de Dios, f. 28v.iños. 
Ya se dijo antes la prevención del padre Molina, como buen franciscano, ante quienes se dedican profesionalmente al comercio. Parece que pensara -en una actitud quizás no demasiado cristiana ni caritativa- que tal tipo de gentes no podrá alcanzar el cielo sino casi por mera equivocación. Reconoce que, originalmente, la actividad de los mercaderes resulta en "pro y utilidad" de la ciudad, pero enseguida se advierte que, para él, es muy raro el tratante que no busca en su actividad sino el camino de hacerse rico engañando a los demás. De cualquier modo, como todavía cree que pudiera llegar a suceder que algún puestero del tianguis se acercara al confesor, no deja de hacerle al hipotético sujeto las siguientes preguntas:

Y tú que eres tratante: y b:uscas la vida, y andas en los tianguez, por ventura no enderezaste la intención de tus tractos y officio de mercader a hazer bien? Quizá no usas deste officio para pro y utilidad de la ciudad: y para favorecer los pobres, ni para tractar justamente, mas para solamente procurar y trabajar de ser rico, o para no más de engañar a los otros, y hurtar, y desta manera, has burlado a los miserables y pobres, a los otomíes, y a los simples, y a los de pequeña hedad? ${ }^{90}$

Finalmente, otro ejemplo de personas a quienes van dirigidas ciertas de las inquisiciones confesionales molinescas son los casados, por ver si es que realmente cumplen con los deberes de su situación civil, así con su esposa como con sus hijos, parejamente situados bajo su responsabilidad de jefes de familia. El cuestionamiento que a ellos les hace va así: "Por ventura has dexado, de tener cuydado, de dar el mantenimiento corporal y espiritual, a los de tu casa, y a toda tu familia: o dexaste de corregirlos y de yrles a la mano, quando en algunas cosas ofendieron a

$90 \quad I b ., 7^{\circ}$ mandamiento de Dios, ff. 35v y 36 . No deja de llamar mucho la atención la reiterada colocación del grupo indígena de los otomíes como ejemplo de sujetos propicios a ser engañados, por su ignorancia, ingenuidad y miseria, en el mismo plano que los pobres, los simples y los niños. 
su Dios y señor: o por ventura los dexaste sin castigo y reprehensión?"'1

Pero el caso es que todos, indios y españoles, casados y solteros, mujeres y hombres, caciques, gobernantes y gente del común, somos pecadores, reflexiona fray Alonso de Molina. No puede dejar de reconocerse la debilidad humana en este sentido: el justo peca, se dice, siete veces al día. Nadie queda fuera de esta generalización: "Que en muchas cosas offendemos y peccamos, y desfallecemos todos". ${ }^{2}$

Tal realidad debe reconocerse. Para cualquier intento de acercamiento a Dios ha de partirse, como de un principio seguro, del sentimiento de la propia culpa ante Él. De ahí la necesidad de que todo cristiano examine su conciencia, objetivo para el cual fue redactado el libro que aquí se comenta. Después, del propio reconocimiento de las fallas y de la comprensión de la grandeza y suma bondad de Aquél en contra de quien se ha faltado, sobrevendrá el verdadero dolor por esa conducta y el deseo de que, con la gracia divina, se pueda cambiar de vida. Dice el franciscano Molina en el prólogo a su Confesionario:

Y por tanto conviene que sepas, que la rayz y fundamento de tu salvación, es el conocimiento de tus pecados y este conocimiento de tus pecados con el qual conoces, y confiesas tus iniquidades, y lo poco que eres es principio y fundamento del conoscimiento de la sabiduría divina; del qual conocimiento, nace también y tiene principio del temor de nuestro señor, y destas dos cosas (conviene a saber) del conocimiento del pecado, y del temor de Dios, tiene principio y procede la contrición y arrepentimiento de los peccados. ${ }^{93}$

Quien se confiesa debe reconocer, además, que las faltas cometidas son absolutamente propias y de nadie más, que él es el único responsable de ellas, que si en las tales incurrió no fue por culpa

\footnotetext{
91 Ib., $4^{\circ}$ mandamiento de Dios, f. 29v.

92 Ib., Prólogo, f. 3v.

93 Ibidem, ff. $4 \mathrm{v}$ y 5 .
} 
de otra persona que de él mismo, que no vale escaparse e intentar inculpar a los demás por haber influido en su acción:

más dirás, es assí verdad que yo quise pecar de mi voluntad; y si yo no quisiera, no cometiera el pecado, porque me ayudara nuestro señor Dios con su gracia, para que yo no cayera en pecado mortal, en el qual cay de mi grado y voluntad, con la qual deseé y cobdicié, y porque lo deseé y cobdicié, y quise, por esso lo cometí luego. ${ }^{94}$

Todos los hombres, en realidad, han cometido pecado; todos, por eso, necesitan de la penitencia y del arrepentimiento para esperar hallar gracia delante del Creador:

Por tanto, tú pecador, has de dezir delante nuestro señor, como dezía el Sabio: el qual confessava sus peccados delante de tu Dios y señor, y le dezía: Señor mío, no me podré tener ni estimar por limpio delante de tu acatamiento, y en ninguna manera podré dezir que es limpio mi corazón, ni tampoco podré dezir que carezca de pecado, y sé también que tampoco lo puede decir ninguno de quantos biven en la tierra, por quanto ninguno con verdad delante de su magestad se puede justificar. Y si alguno dixesse, que estava libre de peccado, estaría muy engañado, y no diría verdad, por quanto somos todos pecadores, y tenemos gran necessidad de hazer penitencia. ${ }^{95}$

Pero, por grande que sea la culpa humana, la misericordia divina todavía resulta mayor: en esta enorme magnanimidad del Todopoderoso, que se apiada del pecador que, arrepentido, acude a implorar su perdón, es en lo que consiste el misterio del sacramento de la penitencia, a ser un útil instrumento para el cual es a lo que quiere dirigirse el libro comentado. El consejo del padre Molina a sus lectores es el de que, cualesquiera que hayan sido sus errores, acudan a confesarse llenos de confianza en el amor de nuestro señor, que no ha de permitir la condenación eterna de los hijos pródigos que han aceptado volver a tomar el camino de su Casa:

9 I Ib., Amonestación, ff. 13 y 13v.

$95 \quad I b .$, Prólogo, f. 4. 
Porque pretendes ayudar a tu ánima y librarla del infierno: y vienes a procurar (mediante tu confessión) la vida eterna, y nuestro criador bienhechor, y piadoso señor Dios te quiere hazer misericordia, y apiadarse de ti, porque no perezcas para siempre, porque no es su voluntad que vaya al infierno aquél que de todo su corazón quiere tornar en sí, y quiere emmendar su vida, y proponer firmemente de no pecar otra vez. ${ }^{96}$

Para ratificarse en todo momento en sus propósitos de no volver a caer en tentación, recomienda fray Alonso a su indio cristiano la oración, fundamentalmente el padre nuestro -el pater noster, lo llama en latín siempre-, el ave María, el credo y la salve, ${ }^{97}$ para dar gracias a Dios de todos los beneficios recibidos y para suplicarle a Él, por la intercesión de sus santos, lo ayude a conservarse fiel a su Señor. Al renunciar solemnemente a su modo anterior de vida, en el texto de la confesión general que se rezaba al dar comienzo a la confesión, ya había pedido el penitente la intercesión de María ante su Hijo para que éste quisiera perdonarle todas sus faltas. ${ }^{98}$

Sólo el sacramento penitencial puede conseguir reinstalar en el pecador la gracia que recibiera primero con el bautismo. Así lo apunta Alonso de Molina en el prólogo de su obra, cuando insta a los indígenas a hacer el análisis de su conciencia,

para que mediante tu confessión merezcas alcanzar otra vez con tu buena diligencia la puridad y dones de nuestro señor Dios, que te fueron dados quando te baptizaste con el agua de Dios, los quales perdiste por tus culpas y pecados, y para merecerlos y alcanzarlos otra vez es necessario trabajar y procurar de exercitarte en la penitencia, por quanto con solo ella, has de ser otra vez alimpiado, y con ella has de alcanzar todos los bienes que por tus pecados perdiste."

96 Ib., Amonestación, f. 8.

97 Por ejemplo, véase $I b$., ler. mandamiento de Dios, ff. 21 y 21 v.

98 Véase $I b$., Confesión general, f. 19v.

99 Ib., Prólogo, f. 7. 
Únicamente por la absolución que habrá de otorgarle el sacerdote, en representación de Jesucristo, podrá el pecador alcanzar la vida perdurable. Son muy hermosas las comparaciones que hace Molina de la situación del alma antes y después de recibir la gracia del perdón de las culpas propia del sacramento de la penitencia: con un enfermo curado por el médico, con un pobre que obtiene limosna de quien puede socorrerlo...

Y tendrás muy gran esperanza en Él, diziendo assí verdaderamente me ayudará y me perdonará todos mis pecados, para que eternalmente yo sea suyo y me llegue a Él: y para que siempre le bendiga en la compañía de todos los ángeles y sanctos: y por esto, quiero echar y alanzar de mí todos mis pecados delante el sacerdote, assí como si yo estuviesse enfermo, quiero descubrir al médico todas mis enfermedades. $Y$ como si yo fuesse pobre quiero manifestar todas mis necessidades a mi señor, y al que me ha de hazer rico: para que aya piedad de mí, y me sane, y dé enteras riquezas y toda abundancia de bienes. ${ }^{100}$

Confesándose, el cristiano que había incurrido en pecado mortal ha podido derrotar al diablo, que anteriormente había vencido sobre él; ¿qué menos que demostrar al Padre un enorme agradecimiento por esa merced?:

... y por tu sacramental confesión has otra vez merecido: alcanzado y hallado la misericordia del único Dios y señor, y has vencido: sobrepujado y burlado a tu gran enemigo Lucifer: y a todos sus fuertes soldados y batalladores: que son los demonios y has totalmente menospreciado sus malas obras assí como si espiritualmente los uviesses ahogado en el mar: y por tanto es justo: que con gran alegría y plazer: alabes y bendigas a tu Dios y señor haziendo oración dando gracias a su magestad. ${ }^{101}$

Por lo demás, para reforzar su pretensión de salvación, los indios mexicanos, como cristianos cabales que son, pueden aprovecharse de la gracia que confieren los demás sacramentos. Frente a los

100 Ib., Amonestación, f. 14.

101 Ib., Amonestación final al penitente, f. 118v. 
autores modernos que han sostenido que los misioneros del siglo Xvı fueron un tanto reticentes en atender a que los naturales se acercaran con frecuencia a recibir la Carne y la Sangre de Jesús que está en la Hostia, pueden traerse a colación las siguientes palabras de fray Alonso, que expresan no sólo un derecho sino una obligación, bien es verdad que un tanto mitigada por la imposibilidad de encontrar siempre a mano sacerdotes que les dieran la comunión. Pregunta, pues, el fraile de San Francisco, a los lectores del Confesionario:

\footnotetext{
Has recebido el cuerpo de nuestro redentor Jesuchristo (assí como te lo manda la sancta madre yglesia?) Porque tienes gran obligación, a recebir cada año el cuerpo de nuestro salvador Jesuchristo en la pascua de resurrección (si tuvieres oportunidad y ministro) y si no la tuvieres, que le recibas quando buenamente pudieres. ${ }^{102}$
}

Tocante a los sacramentos que reciben los indios, resulta particularmente interesante un punto sobre el cual insiste mucho nuestro fraile franciscano en este libro del Confesionario mayor en la lengua mexicana y castellana. Se mencionó páginas atrás que el único sacramento del cual no hay ninguna alusión para su otorgamiento a los naturales es el del orden sacerdotal; tal situación indica que, para los misioneros de la época, no era oportuno conferírselos por entonces. En cambio, la que sí es enorme es la importancia que se da al matrimonio, a cuya explicación y preparación dedica el libro buen número de hojas.

Según y como se presenta allí, la vida matrimonial es, para los indígenas, que no han de ser nunca sacerdotes, la natural situación existencial dentro de la cual han de alcanzar su salvación. No se trata sólo de que, casándose, puedan ir al cielo los naturales sino, más bien, de que ha de ser, precisamente, la boda religiosa primero y luego la cristiana vida marital de los esposos, el

$102 \mathrm{Ib}, 4^{\circ}$ mandamiento de la Iglesia, f. $69 \mathrm{v}$.

118 C 
medio a través del cual conseguirá la mayoría de ellos las gracias necesarias para su justificación.

Claro que, antes de casarse, los nativos de esta tierra deben haber entendido ya muy bien qué es lo importante en el matrimonio, cuáles son los fines cristianos a buscarse con la boda, tal el de

... que endereceys la intención de vuestro casamiento a nuestro Señor, casándoos por su amor, y no por la suzia delectación de la luxuria, ni por las riquezas, y bienes mundanales, o por alguna altivez de sobervia, o vanagloria (assí como lo hazen los infieles y los males christianos) mas por amor y respecto de nuestro señor Dios, para agradarlo y complazerle con vuestro matrimonio: y para aver hijos, los quales en este mundo, y en el cielo, alaben y glorifiquen para siempre a su Majestad. ${ }^{103}$

No puede ser más clara la definición del matrimonio como institución sacramental a través de la cual va a poder alcanzar el hombre -y la mujer, claro; la pareja- su justificación. Allí, lo que fuera del sagrado vínculo es pura lujuria, se convierte en expresión del mutuo amor conyugal y en instrumento para la procreación de nuevos servidores y alabadores de Dios. Dice el padre Molina:

Pues os ha ayuntado en uno nuestro señor, para que os salveys: porque tú que eres varón te librarás por tu muger, y descansará con ella tu corazón, y tu carne (quando el demonio te tentare de alguna tentación de luxuria) y de la misma manera, tú que eres muger, te librarás por tu marido; quando fueres tentada. Y por tanto os es muy necessario, que os obedezcays el uno al otro, acerca del débito. ${ }^{104}$

Por el matrimonio, los esposos han pasado a ser el uno propiedad del otro, han dejado de pertenecerse individualmente, de modo que ya no pueden disponer libremente de su cuerpo, puesto que

103 Ib., Matrimonio, f. 53v.

10. Ibidem, f. 54. 
éste ya no es sino instrumento de los fines trascendentes de la divinidad: la santificación de los instintos carnales, la procreación: "y acerca de la obediencia que el uno al otro os deveys de tener en pagar el débito, conviene que sepays, que el cuerpo del varón: casado por la yglesia, ya no es suyo: sino de su muger (avida por matrimonio) y el cuerpo de la muger, no es ya suyo, sino de su martido, etc." 105

La salvación de cada cónyuge ha pasado a ser responsabilidad del otro; en eso consiste, fundamentalmente, el amor que se deben tener los esposos. Por virtud de su casamiento, el contrayente ha quedado entrañablemente comprometido en la justificación de su pareja:

Assí mismo os aveys de casar para ayudaros spiritualmente el uno al otro: porque tú que eres varón tienes obligación a favorecer y ayudar a tu muger, en las cosas tocantes a su salvación, provocándola quanto pudieres, a bivir sanctamente: e importunándola a que sirva y obedezca a nuestro señor Dios, y a la guarda de sus mandamientos, y a que no haga ni cometa alguna maldad estorvándola, quando quisiere hazer algún desatino, y la misma obligación tienes tú, que eres su muger conviene a saber, de favorecerle y ayudarle a salvar. ${ }^{100}$

Naturalmente, este mutuo deber de auxiliarse recíprocamente los dos cónyuges también ha de referirse a las cosas materiales. A cada quien le toca cumplir con un conjunto específico de obligaciones, todas igualmente importantes para la vida de la pareja y para la buena marcha de los asuntos familiares. El párrafo que se copia ahora del Confesionario mayor... de fray Alonso de Molina, correspondiente a la Amonestación que ha de hacer el sacerdote antes de proceder a casar a los novios, resulta hermosísimo compendio de los deberes propios de cada esposo para la vida coti-

$105 \quad I b .$, ff. $54 \mathrm{v}$ y 55.

106 Ib., ff. 55 y $55 \mathrm{v}$. 
diana de la familia los cuales, a fin de cuentas, han de repercutir hasta en el conjunto de la sociedad; va de esta guisa:

También aveys de pretender de casaros, para os ayudar corporalmente: por quanto soys obligados de favorescer el uno al otro, en vuestras necesidades corporales, porque el officio del varón es, trabajar fuertemente, para adquirir lo necesario a su persona (conviene a saber) su proprio sustentamiento y el de su mujer, y hijos y para que tenga con qué socorrer a los pobres, y enfermos, a los viejos y viejas, los quales no pueden ya trabajar, y para que tengan algo que ofrecer en la yglesia, delante su Dios y señor, llevando y presentando alguna cosa en las fiestas principales, o entre año: y para ayu(lar y favorecer a su ciudad, dando su tributo, etc. $Y$ por tanto no es justo que en algún tiempo estés ocioso tú que eres varón, más que tengas gran cuydado de tu especial oficio y el mismo cuydado ha de tener la muger, para ayudar a su marido: porque es obligada a guardarle la hazienda, y a estar en casa, y a barrer, lavar y fregar, a hilar, texer, moler y guisar de comer, criar los hijos, y a tener gran cuydado de su marido (quando enfermare) consolándole, y ocupándose en su servicio, y honrándolo mucho y la misma obligación tiene el varón, de tener gran cuydado de su muger (quando estuviere enferma) buscándole las medicinas, y llamando al médico: y guisándole de comer, importunándola mucho a que coma el manjar, y tratándola bien (especialmente quando estuviere preñada) y honrándola mucho. ${ }^{10 \overline{\bar{x}}}$

En fin, la vida toda del hombre, en su tensión hacia la salvación, se desarrolla entre las propias obras y la labor salvífica, imprescindible, de la gracia. Cunviene recordar que uno de los principales motivos de discusión, por aquella época, entre católicos y protestantes, era alrededor de este problema. Resulta muy clara exposición de la doctrina de la Iglesia sobre la materia la que hace fray Alonso al tratar de la virtud de la esperanza; allí explica muy bien cómo son ambas instancias, la gracia y las buenas acciones, las que han de llevar a la persona humana a la gloria:

$107 I b .$, ff. 55 v y 56. 
Dixiste por ventura alguna vez, nuestro señor Dios me dará el reyno de los cielos, y la gloria del parayso, solamente por las buenas obras y bienes que hazes? Porque creyendo tú esto assí: estás muy engañado y errado por quanto más princippalmente, por la merced y misericordia de nuestro señor Dios, se alcanza el reyno de los cielos y la gloria del parayso, y no principalmente, por tu bondad y buenas obras, que por tu proprio motivo heziste, aunque también serás salvo, mediante las dichas buenas obras: por quanto son necessarias dos cosas para alcanzar la salvación, conviene a saber, la gracia de nuestro señor y las buenas obras que hazemos a nuestra voluntad y de buena gana. ${ }^{108}$

En última instancia, ese era el problema central del catolicismo en el siglo de la Contarreforma en cuanto a la importancia de la conducta del hombre sobre la tierra: el hombre debía esforzarse por vivir bien, adecuándose a los preceptos dictados por Dios y por la Iglesia, pero lo que en definitiva le concedía la justificación, lo que lo redimiría del pecado en que por su propia voluntad había caído, era la obra redentora de Jesucristo, la gracia que le mereció por su sacrificio, muerte y resurrección. El propósito central del Confesionario mayor en la iengua mexicana y castellana fue, ante todo, el de poner al cristiano neófito, al recién convertido de estas tierras mexicanas entonces nuevamente incorporadas al orbe occidental en conocimiento de cómo había de vivir, de cuáles habían de ser sus obras, para que se reconociera pecador, se propusiera firmemente la enmienda y, humilde, acudiera a recibir, con la confesión de sus faltas, la merced de la absolución que habría de restituirlo a la gracia de Dios.

Ib., Esperanza, ff. 108v y 109. 